\title{
SOEP
}

SOEPpapers

SOEPpapers
on Multidisciplinary Panel Data Research

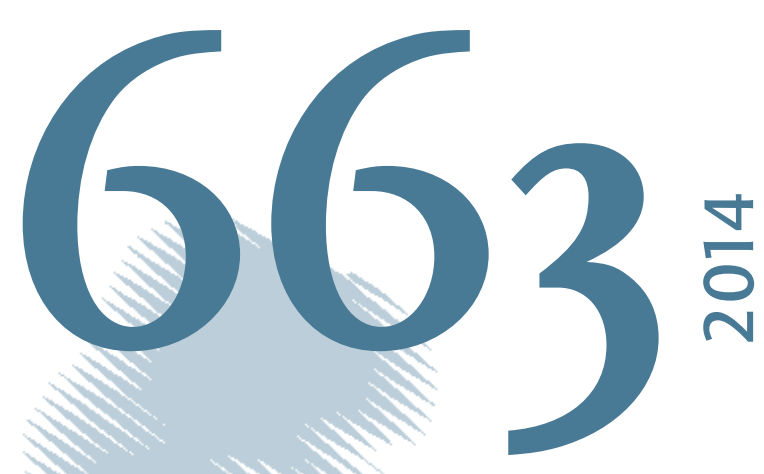

\section{The German part-time wage gap: bad news for men?}




\section{SOEPpapers on Multidisciplinary Panel Data Research}

at DIW Berlin

This series presents research findings based either directly on data from the German SocioEconomic Panel Study (SOEP) or using SOEP data as part of an internationally comparable data set (e.g. CNEF, ECHP, LIS, LWS, CHER/PACO). SOEP is a truly multidisciplinary household panel study covering a wide range of social and behavioral sciences: economics, sociology, psychology, survey methodology, econometrics and applied statistics, educational science, political science, public health, behavioral genetics, demography, geography, and sport science.

The decision to publish a submission in SOEPpapers is made by a board of editors chosen by the DIW Berlin to represent the wide range of disciplines covered by SOEP. There is no external referee process and papers are either accepted or rejected without revision. Papers appear in this series as works in progress and may also appear elsewhere. They often represent preliminary studies and are circulated to encourage discussion. Citation of such a paper should account for its provisional character. A revised version may be requested from the author directly.

Any opinions expressed in this series are those of the author(s) and not those of DIW Berlin. Research disseminated by DIW Berlin may include views on public policy issues, but the institute itself takes no institutional policy positions.

The SOEPpapers are available at

http://www.diw.de/soeppapers

\section{Editors:}

Jürgen Schupp (Sociology)

Gert G. Wagner (Social Sciences, Vice Dean DIW Graduate Center)

Conchita D'Ambrosio (Public Economics)

Denis Gerstorf (Psychology, DIW Research Director)

Elke Holst (Gender Studies, DIW Research Director)

Frauke Kreuter (Survey Methodology, DIW Research Professor)

Martin Kroh (Political Science and Survey Methodology)

Frieder R. Lang (Psychology, DIW Research Professor)

Henning Lohmann (Sociology, DIW Research Professor)

Jörg-Peter Schräpler (Survey Methodology, DIW Research Professor)

Thomas Siedler (Empirical Economics)

C. Katharina Spieß (Empirical Economics and Educational Science)

ISSN: 1864-6689 (online)

German Socio-Economic Panel Study (SOEP)

DIW Berlin

Mohrenstrasse 58

10117 Berlin, Germany

Contact: Uta Rahmann | soeppapers@diw.de 


\title{
The German part-time wage gap: bad news for men?
}

\author{
Elke Wolf \\ University of Applied Sciences Munich \\ E-mail: elke.wolf@hm.edu
}

May 2014

\begin{abstract}
:
Despite the increasing incidence of part-time employment in Germany, the effects on wage rates are studied rarely. I therefore use SOEP panel data from 1984 to 2010 and apply different econometric approaches and definitions of part-time work to measure the socalled part-time wage gap of both, men and women in East and West Germany. A very robust finding is that part-time working men are subject to higher wage penalties than women. Accounting for all available observed as well as time-constant unobserved individual characteristics yields a wage cut of about 10 percent in East and West Germany. Furthermore, the type of contract makes a big difference. While marginal employees earn considerable lower wage rates, irrespective of region and sex, reduced working hours covered with social security do not seem to be to the detriment of women once differences in observed characteristics are taken into account. Fixed-effects panel estimates even yield slightly benefits from working part-time. Nonetheless, long part-time spells may cause financial drawbacks for women, because experience in part-time employment generates lower or even no positive returns. Another novel of my study is the look the part-time wage gap over the years. The empirical evidence reveals that wage differentials in WestGermany increased over time. Since this trend disappears for men, as soon as individual fixed-effects are disentangled, I suppose that selection of men with progressively unfavourable labour market characteristics triggered this downward slope. In contrast, the downtrend of the female part-time wage gap seems to be caused by the increasing share of marginal employees, who exhibit a significant and larger wage cut compared to standard part-time women.
\end{abstract}

Keywords: Part-time work, wage structure, working hours.

JEL Classification: J22, J24, J31. 


\section{Introduction}

Part-time work became more and more popular in the last decades. In Germany, about one quarter of all employees work reduced hours and the employment growth in the last decade was solely driven by the expansion of part-time employment (Eurostat 2013). In 2010, the part-time share among West-German male employees was almost four times higher than in the year 1984, when it amounts to negligible 1.5 percent. The corresponding share for female workers increased from 27.9 percent in 1984 to 48.7 percent in 2010. Also in East Germany, reduced working hours became widespread in the meanwhile. While the parttime share among men is higher than in West Germany (11.3 percent), women are less likely to work part-time compared to their West German colleagues (34.6 percent) (Statistisches Bundesamt 2012). This trend can also be observed in many other OECD countries, especially in the Netherlands, Austria, Italy, Ireland, Belgium and Spain. With the exception of Italy and Spain, growth in part-time employment has been predominantly voluntary (OECD 2010).

Although survey-based data show that a fair amount of part-time employees want to upward adjust their working hours, the rise in part-time work has been predominantly voluntary (Holst 2009, Holst and Seifert 2012, OECD 2010). Hence, part-time employment seems to correspond largely to the preferred employment status. According to the answers in the SOEP, only 22 percent of all part-time employees do so because they cannot find a full-time position. Interestingly, this share increased significantly between 2001 and 2005 with almost 35 percent of men lacking an appropriate full-time job offer (Brenke 2011). Allart and Bellmann (2007) can show that employees' preferences represent the most important motive for the incidence of part-time jobs in Germany and the Netherlands. Hence, demand-side factors play a minor role in explaining the increase in part-time employment (see also Euwals and Hogerbrugge (2006) for the Netherlands).

Employees' reported reasons for working part-time provide some insight into their labour supply decisions. About one fourth of all part-time employees work reduced hours in order to look after children or other family members in need for care. Another 20 percent refer to other family related motives for part-time employment. Time requirements for training and continuing education represent an additional reason for working part-time. While this motive is the driving force for about 10 percent among women, more than a quarter of all part-time working men reduce their hours in order to invest in human capital (Brenke 2011).

As demographic and technological change are accompanied by an increasing need for continuous training to catch up with new technologies (see e.g. Fischer et al. 2008, Leszczensky et al. 2009, Riphahn and Trübswetter 2007), the trend in part-time employment is unlikely to reverse in the near future. In contrast, part-time work as a way to adapt to the changing conditions on the labour market will become both more demanded in the future and essential for the society to tackle with the challenges of internationalization, technology and demography. As stated by Bosch et al. (2010), the part-time employment model is indeed here to stay for some more time. 
Several new laws, entitling employees in Germany to reduce their working hours if no urgent organisational problems occur, are supposed to ease the adoption of contracted working hours. With the exception of older workers, all workers can automatically return to their fulltime hours if desired (Part-Time Work and Fixed-Term Employment Contracts Law [TzBfG], Nursing Care Leave Act [PflegeZG]). As a result of this rather generous part-time request regulation, the share of full-time female workers aged between 25 and 49 years with caring responsibility wanting to work fewer hours amounts to 6 percent only and is lower than in most other OECD countries (OECD 2010).

In practice, the increasing individual desire and social need to work at reduced hours does not and will not always correspond to the job offers available. Incompatibilities between labour supply preferences and labour demand decisions are not only a matter of unfulfilled preferences, though. Apart from negative effects on workers' health and subjective wellbeing (Bell et al. 2012, Constant and Otterbach 2011, Grözinger et al. 2008, Wooden et al. 2009), there exists a growing body of literature showing that hours restrictions may also impair the adequate matching of skills to jobs. Adjusting actual working hours towards preferred hours is often bought by job-to-job mobility or even occupational mobility. Job mobility, however, does not only cause frictional costs, but might also induce a loss of human capital and wages, in general (see e.g. Connolly and Gregory 2008 for the UK).

Wage cuts for part-time employment may be interpreted as compensating wage differentials for favourable work-time schedules or may be caused by labour demand-side economic factors (such as higher labour costs or reduced productivity). They may also be a result of discrimination, though. Theoretically, all three types of discriminating behaviour may occur: (i) preferences for discrimination, (ii) statistical discrimination or (iii) monopsony power.

Irrespective the source of the part-time wage gap, lower wage rates for part-time employees may induce negative labour supply effects (O'Reilly and Bothfeld 2002) and intensify the ongoing skills shortage caused by demographic change and globalised markets, the shrinking fertility due to increasing problems to reconcile work and family life and the shortage of time in households with family members in need of care. Thus, a careful look on the relative remuneration of part-time employees is essential.

The empirical identification of wage cuts for part-time employees is not trivial, though. While labour supply theory implies that employment as well as the desired number of hours worked is determined by the wage rate, there exists a bunch of economic reasons why working hours may affect wages. Simple regressions of wage functions are hence biased due to endogeneity. The instrumental variable approach, any type of Heckman-selection models and simultaneous wage-hours-models are extensively used to tackle this issue (Blank 1990, Bardasi and Gornick 2000, Wolf 2002, Gustafsson et al. 2003, Baffoe-Bonnie 2004, Rodgers 2004, Hardoy and Schøne 2006, Manning and Petrongolo 2008, Wahlberg 2008a and 2008b, Wilson 2010 as well as Matteazzi et al. 2012). Since the exclusion restrictions typically used in these studies (number and age structure of the children in the household, marital status, other family income) rely on rather strong and partly unrealistic assumptions, Manning und Petrongolo (2008) argue that the exogeneity assumption underlying the ordinary least 
square estimates may not be worse. Aaronson und French (2004) are the only ones who use an institutional characteristic of the U.S. social security system as a true exogenous instrumental variable for working hours. Using panel data is hence a promising alternative to disentangle the wage effect of time-constant and unobserved characteristics from the true impact of working hours (see e.g. Hirsch (2005) for the U.S., Booth and Wood (2008) for Australia, Connolly and Gregory (2008) as well as Wilson (2010) for Great Britain, Kranz and Rodriguez-Planas (2011) for Spain, Russo and Hassink (2008) for the Netherlands). The majority of these studies detect significant negative wage effects of part-time employment. Furthermore, there exists some empirical evidence that part-time spells yields lower returns to experience compared to full-time employment (Beblo and Wolf 2002, Olsen and Walby 2004, Hirsch 2005, Russo und Hassink 2008, Fernandez-Kranz et al. 2011), the implication being that wage growth for full-timers is higher than for part-timers (Manning and Robinson 2004). Therefore, the exact accommodation of work histories is crucial to distinguish between current and long-term effects of reduced working hours.

The list of studies about the part-time wage gap in the German labour market addressing these issues is very short, though. Brehmer and Seifert (2008) as well as McGinnity and McManus (2007) use German panel data from 1989 to 2007 and run fixed-effects wage regressions. However, potential differences between the returns to experience in full-time and part-time jobs and hence the impact of past part-time spells during the work history is not considered. Paul (2012) estimates a trivariate random-effects model in order to accommodate both the endogeneity of actual and past working hours of German women as well as unobserved heterogeneity and selection. They all conclude that the initial gap in observed wages of women is more or less closed once individual characteristics and occupations are taken into account. Part-time working men, however, are subject to higher wage cuts in permanent as well as in fixed-term employment (Brehmer and Seifert 2008). All existing studies neither look at differences between East and West-Germany, where the extent of part-time work differs significantly, nor at the evolution of part-time wage gaps over time.

The aim of this paper is therefore to provide a comprehensive analysis on the wage structure of part-time and full-time working men and women in East and West-Germany in the period between 1984 and 2010. The results contribute to the existing literature in four dimensions. First, I use time series data from the German Socio Economic Panel (SOEP), permitting to measure unbiased wage effects of part-time work. Second, I exploit the comprehensive information on individual work history and many other labour market characteristics in order to disentangle short- and long-term effects of part-time employment. Third, the long time-series allow me to first detect potential shifts of the part-time wage gap in Germany. Given the increasing importance of part-time employment and the new legislation in favour of part-time employees, their relative remuneration may have changed over the years. Finally, I investigate the wage structure separately for men and women in East and West Germany such that differences in the wages are easily comparable. Since wage cuts tend to be even higher for men, this study enriches the scanty research in this field. 
The following section briefly summarizes economic approaches to understand the part-time wage gap. Section 3 describes the data in use and the construction of the hourly wage rate variable. I also provide a first look on the distribution of working hours and wages. The econometric approach to measure the effect of working hours on wage rates is expounded in section 4 and the empirical results are presented in Section 5 . The final section concludes.

\section{Economic Theory and the trend of the part-time wage gap over time}

Economic theory provides several explanations for the dependence of hourly wages on the number of working hours. The part-time wage gap may hence be due to differences in (1) labour costs, (2) productivity, (3) preferences for specific workplace characteristics or result from (4) discrimination. Finally, the institutional framework (5) shapes the distribution of wages for jobs with reduced working hours. In the following, I briefly expound the theoretical concepts and then derive hypotheses concerning the trend of the resulting parttime wage gap over the years.

Labour costs of firms do not increase proportionally with hours worked, because part-time jobs cause relatively higher fixed costs (for example, recruiting and training costs, arranging a work place and coordination costs). As a result, firms' willingness to pay for part-time employees tends to be lower than for full-time employees (see e.g. Oi 1962 or Montgomery 1988). Hamermesh und Rees (1988) can show that these fixed costs increase with the qualification level of employees, inducing even higher wage cuts of high-skilled part-timers. Lindbeck and Snower (2000) argue that also employees in "holistic" organisations, endowed with extended decision-making authority and responsibility, working in teams and sharing jobs by multitasking, require higher investments in training than employees in so-called "tayloristisic" firms. Unless the organization of work across employees explicitly accommodates the possibility of reduced working hours, holistic organisations are more likely to pay lower wage rates for part-time employees due to higher costs for training and reorganisation. The dissemination of holistic organisations, their side effects on the demand for high-skilled workers (Caroli and Van Reenen 2001 or Bresnahan et al. 2002) and the bewailed shortage of skilled workers are therefore factors driving the part-time wage cuts over the years. However, even the scattered cut in working hours of high-skilled employees or managers generates valuable expertise in organizing part-time work efficiently and may hence contribute to limit the labour costs of part-time employment over the years. These converse effects do not justify a clear trend in relative part-time wage rates, though.

Secondly, the number of working hours may also affect productivity and hence the firms' willingness to pay. Barzel (1973) argues that productivity will first rise slowly due to "startup" effects at the beginning of a working day. Thus, the productivity of the last hour of a "normal" working day still exceeds the average daily productivity, which leads to lower wage rates for part-time workers. If, however, the fatigue effect occurs before the standard eight hours shift, reduced working hours may raise hourly productivity (Moffit 1984; Tummers and Woittiez, 1991). Furthermore, shorter hours may reduce unproductive time, or "slack". In this setting, part-time wages should be higher (Booth and Wood, 2008). In contrast, the 
literature on contract theory with asymmetric information argues that long working hours can serve as a screening instrument to detect workers with high motivation, strong commitment and presumably higher productivity to the firm (Landers et al., 1996). This approach is, however, based on the assumption that the correlation between working hours and productivity is positive. Hence, the link between working hours and productivity is theoretically inconclusive, but there is no reason to believe that it has changed over the years.

The theory of compensating wage differences represents the third source of wage differentials. Job characteristics as well as preferences for specific working conditions may vary by the number of (desired) working hours and hence give reasons for positive or negative wage differentials (Rosen 1986). Reduced working hours, for instance, aiming to facilitate the reconciliation of work and family life, but increasing the organizational effort on the part of the firm, would cause a wage cut for part-timers. Contrary, the use of part-time employees may improve total productivity (e.g. if opening hours can be expanded) and hence raise the willingness to pay for these nonstandard contrasts. Given the evidence that part-time employment in Germany is less triggered on behalf of the firms, but rather conform to employees' preferences (Allaart und Bellmann 2007), the theory of compensating wage differentials predicts negative wage cuts for part-time employees. Again, there exists no obvious reason to believe that these facts have changed over time.

Fourth, any type of discrimination may affect the relative remuneration of part-timers. While the taste for discrimination may be less relevant in this context, statistical discrimination is likely to emerge. Unequal treatment may, for instance, be triggered by the notion that parttime workers are less dedicated to the labour market, less productive and less flexible. These stereotypes tend to be lower in companies with more part-timers, more precisely, with more heterogeneous part-timers. According to the cross-country study of part-time employment by the OECD (2010), the part-time wage penalty tends to be lower in countries with higher part-time shares, where employers are accustomed to alternative working time schemes. This pattern is especially clear for men (OECD 2010). Also Bell and Freeman (2001) argue that wage cuts for male part-time employees are especially high, if very long working days represent the social norm. Deviations from the standard working time model are then interpreted as a negative selection. Applying this hypothesis to the long run, I expect the part-time wage gap to shrink over the years, because the everyday experience with parttime employees alter the employers' assessment of part-time workers in general. Apart from the changing numbers, the introduction of the Part-Time Work and Fixed-Term Employment Contracts Law in 2001 strengthened the rights of employees and helped to establish parttime work as one of different standard working-time regimes.

Also discrimination based on monopsony power may come into play. Ermisch and Wright (1991) argue that part-time workers are not only less willing to accept long commuting times than full-timers, but they are also less likely to move because in general part-time workers are female and second earners in the household. As a result, their labour supply is likely to be less elastic than the supply of full-timers, which generates monopsonistic power. The 
basic idea of the "new" monopsonistic approach is that employers have market power despite competition with other firms. The sources of potential market power are manifold, though. In the "modern" sense, labour markets are "thin", if opportunities to change jobs are rare (Manning 2003). Bhaskar et al. (2002) argue, for instance, that workers may have heterogeneous preferences for non-wage job characteristics, i.e. the job specification, hours of work, work time flexibility, distance between the firm and the worker's home and the social environment in the workplace, such that workers may choose their jobs in favour of specific working conditions. The key implication of market power, irrespective of its source, is that labour supply elasticity is lower compared to the benchmark model of perfect competition. Meanwhile, there exists widespread evidence of limited labour market competition in many countries (see e.g. the surveys of Ashenfelter et al. 2010 or Manning 2011). The link between monopsonistic power and part-time wages is not analysed, though. Whether the market power of firms offering part-time jobs and the resulting wage gaps changed over time, is also an open question. On the one hand, employees reveal stronger preferences for reduced working hours over the years (Holst 2007; Holst and Seifert 2012), be it to care for children or older family members or to continue training. Furthermore, employees have the right to reduce working hours since 2001 (Part-Time Work and FixedTerm Employment Contracts Law [TzBfG]). On the other hand, the incidence of part-time employment constantly increased in all fields over time, such that hours restrictions should have loosened. In Switzerland, there even exists a web portal offering more than 10 thousand qualified part-time jobs (www.teilzeitkarriere.dom). In general, I suppose that discriminating behaviour lost ground during the last years if the new labour market regulations establishing the rights of part-time employees ( $\$ 4$ Abs. 1 TzBfG) actually constrain employer's discretion.

Fifthly, the institutional framework may affect hourly wage rates. Most of the jobs without social security coverage, the so-called "marginal jobs", are taxed by a lump sum tax at the expense of the employer (30 percent since 2006), exceeding the costs of fringe benefits for employees with social security coverage. The empirical results of Schwarze (1998) lead one to suppose that employers shift part of the tax burden on to the marginal employees, resulting in a wage cut of nearly $15 \%$ compared to full-time employees. Marginal employees, married women for the most part, are willing to accept these lousy wages in general, because earnings above a certain threshold are filed with a very high marginal tax rate due to German marital status reliefs (Voss and Weinkopf 2012). In the end, the employer can benefit from the specifics of marginal employment and the German tax system. Marginal jobs may therefore be subject to higher wage cuts than part-time jobs covered by social security. Again, the TzBfG strengthened the rights of employees, such that the relative remuneration of employees with marginal jobs is expected to have improved over the years.

In short, there are many economic reasons to suppose that there exist wage differences between full-time and part-time jobs in Germany, and especially between jobs with and without social security coverage. In theory, the resulting wage gap could be either positive or negative, depending on the importance of the different effects. In practice, however, there is little empirical evidence for wage premiums for part-time jobs (OECD 2010, Booth and Wood 
2008). As to the temporal change of the part-time gap, the theoretical implications are also not clear-cut. An empirical analysis on the wage differential between full-time and part-time workers and its long-term changes in Germany is hence straightforward.

\section{Data and Description of the Sample}

The empirical analysis is based on 27 waves of the German Socio Economic Panel (SOEP) (Wagner et al. 2007). The SOEP is a yearly microdata panel which has been conducted in annual interviews of individuals and households since 1984 in West Germany and since 1990 in East Germany. The first census in 1984 covered almost 6000 households, whereof 4500 are sampled randomly from the West-German population. The other 1500 households represent a stratified sample of immigrants of guest workers from Italy, Spain, Turkey, Yugoslavia and Greece who lived in Germany in the period during which the interview was conducted. In the meanwhile, several additional samples are drawn, amongst others East German households (since 1990) and three supplement samples of German households (1998, 2000 and 2006).

To study the wage structure, I dropped all self-employed and those working in the farming sector. Furthermore, I restrict the sample to employees aged between 20 and 60 years who are not in apprenticeship in the period during which the interview was conducted in order to exclude peculiarities due to the stepwise entry into the labour market after schooling or vocational training and partial retirement programs. Finally, all observations with missing labour market information are excluded. The final sample contains 7350 individuals in 2010 and almost 183.000 observations in all 27 survey years.

The SOEP only provides information on weekly working hours and last month's salary. Hence, the definition of hourly wage rate is of mayor importance for the analysis of the parttime wage gap. In principle, I use agreed weekly working hours to calculate the hourly wage rate. ${ }^{1}$ Since actual work time may differ from the agreed working hours, I define three cases where average actual working hours instead of agreed working hours are used to determine hourly wage rates:

(1) Overtime hours are paid (if average actual working hours are not available, I take the sum of agreed working hours and the number of overtime hours of the last month).

(2) Overtime hours are not compensated at all (if average actual working hours are not available, I take the sum of agreed working hours and the number of overtime hours of the last month).

(3) Agreed working hours are missing and reported overtime hours are zero.

\footnotetext{
${ }^{1}$ Buligesu et al. (2009) note that actual working hours in the SOEP - observed for only one week - exhibit considerable dispersion, which induces a spurious negative correlation between the working hours and the calculated wage rate and hence bias the estimated part-time effects downwards.
} 
Furthermore, missing agreed working hours are imputed if all other variables hint at active employment. Individuals whose employment status indicate full employment and overtime work happens, but is not disbursed, are assumed to work under a 40-hours contract, parttime employees agreed on a 20-hours contract and marginal employees are assumed to work 10 hours on average. ${ }^{2}$

In all these cases, however, the information on working hours I use may differ from the number of working hours referring to the salary of the last month. To capture this imprecision of the calculated hourly wage rate, I generate a dummy-variable equal to one if the hourly wage rate is not based on agreed working hours. Since the figures barely change, I first present the results without this auxilliary dummy variable and discuss the alternative estimation results in section 5.3.

Figure 1: Distribution of agreed weekly working hours in 2010

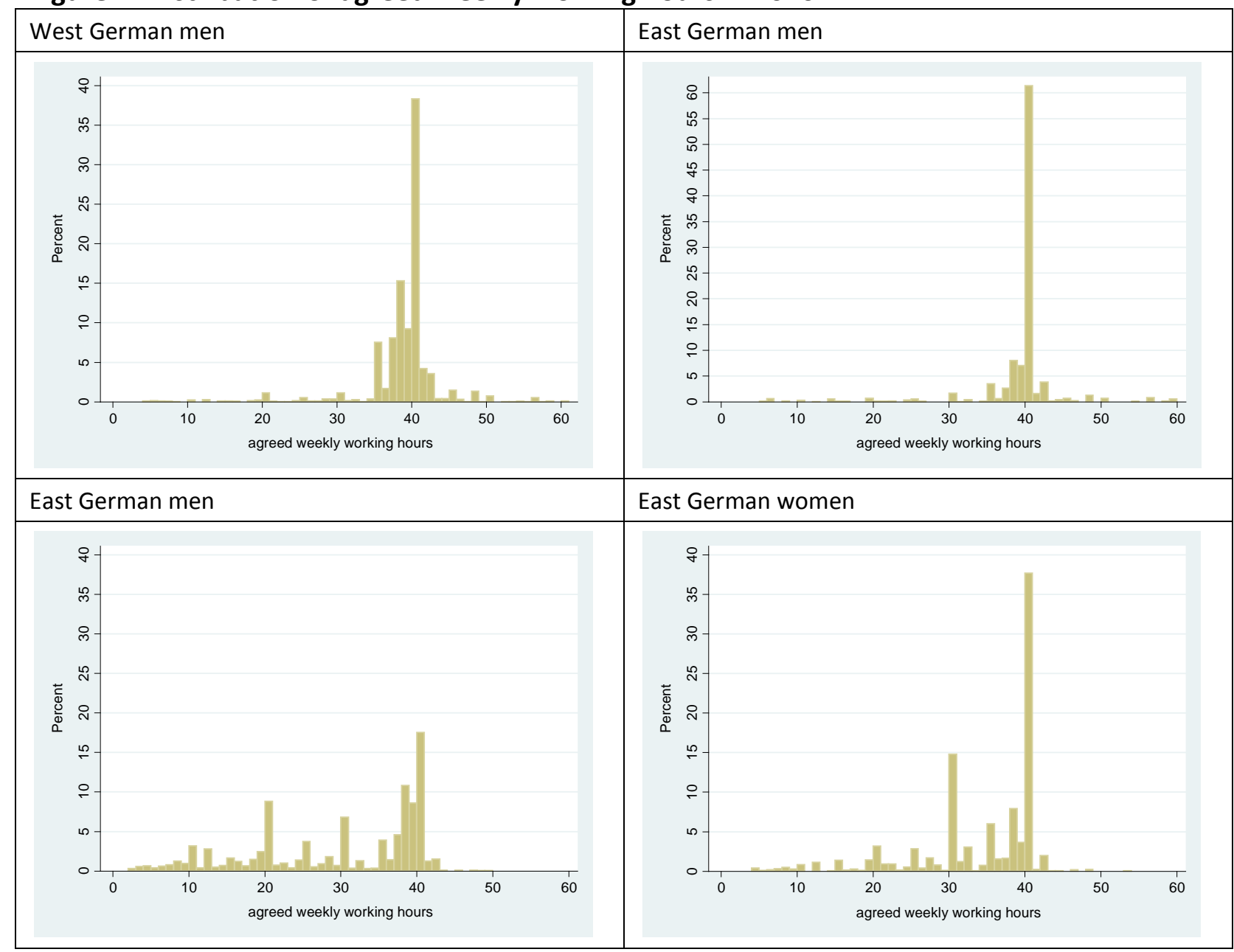

Source: Own calculations based on the selected sample of the SOEP 2010 (weighted figures).

The distribution of agreed weekly working hours is illustrated in Figure 1. Men and East German women exhibit a major peak at 40 hours. Among East German men, more than 60

\footnotetext{
${ }^{2}$ The imputed working hours represent the most frequent number of agreed working hours within the corresponding employment status.
} 
percent of all employees work these standard full-time hours. Among West German men, weekly working hours between 37 and 40 hours cover almost all other contracts. West German women exhibit a distribution with three peaks, namely at 20, 30 and 40 hours, whereby the peak at 40 hours is still the highest. But also the hours categories in between are represented in our sample. East German women have a bimodal distribution of working hours with a second smaller peak at 30 hours. As expected, hourly wage rates vary by the number of working hours. Table 1 shows the average wage rates of five working hour regimes. In West Germany, employees with less than 15 hours per week - presumably marginal jobs for the most part - earn the lowest wage rates. Compared to full-time contracts, the wage cut for small part-time jobs ( $\geq 15$ and $<25$ hours) amounts to almost 3 Euros for men and 2 Euros for women. But also employees with extended part-time jobs ( $\geq$ 25 and $<35$ hours) earn lower wage rates than full-timers. The wage rates for East German part-time working men are difficult to interpret due to the low number of observations and the wage distribution for women is rather flat. Hourly wage rates of employees working more than 45 hours per week are in general rather lower, which may partly be ascribed to uncompensated overtime work or the imprecision of the calculated hourly wage rate in case of paid or uncompensated overtime hours.

Table 1: Hourly wage rates (in Euros) by number of weekly working hours (2010)

\begin{tabular}{|c|c|c|c|c|}
\hline & \multicolumn{2}{|c|}{ West Germany } & \multicolumn{2}{|c|}{ East Germany } \\
\hline & Men & Women & Men & Women \\
\hline Weekly working hours $<15$ hours & 9.48 & 11.08 & 7.20 & 12.86 \\
\hline Weekly working hours $\geq 15 \&<25$ hours & 15.87 & 13.55 & 16.08 & 12.54 \\
\hline Weekly working hours $\geq 25 \&<35$ hours & 17.45 & 14.06 & 13.07 & 12.07 \\
\hline Weekly working hours $\geq 35 \&<45$ hours (full-time) & 18.54 & 15.52 & 13.74 & 13.11 \\
\hline Weekly working hours $\geq 45$ & 14.79 & 11.95 & 13.72 & 9.09 \\
\hline Number of observations & 2781 & 2875 & 826 & 868 \\
\hline
\end{tabular}

Source: Own calculations based on the selected sample of the SOEP 2010 (weighted figures). The shaded numbers correspond to less than 50 observations and should hence be interpreted with caution.

It is not surprising that part-time and full-time employees do not only differ as to wages, but also in terms of education, work history, occupations, individual characteristics and their distribution across firms. Table 7 in the Appendix presents the means of labour market relevant variables by region, gender and working time regime. As to education, it is interesting to note that men with reduced working hours are much more likely to have a university degree than full-time employees. In contrast, the share of female part-time employees with a degree is smaller than the corresponding figure for full-time women. A universally valid finding is that the share of unskilled employees is higher among part-timers.

The distribution of part-time employees across firms also shows some specifics. First, male part-timers are more often employed in the public sector and in the service sector than fulltimers. The opposite holds for East German women. Second, employees with reduced working hours avoid or are excluded from the more traditional industry sectors (except the textile industry). Third, smaller firms are more likely to integrate employees with reduced working hours in West Germany. Since overtime hours and the reorganisation of work 
cannot yield many resources in small businesses, they rely on flexible working hours to adjust for demand shocks, extend the operating time and improve firm's competitiveness.

Finally, the figures illustrate that deviations from standard full-time employment is not a short-term phenomenon, but correlates strongly with the employment history. Employees working reduced workings hours today spent more years in part-time employment and fewer years in full-time employment than current full-timers. Furthermore, overall work experience is smaller and the mean sum of unemployment spells is longer among parttimers. Presumably, employees with shorter hours also exhibit less firm-specific human capital because mean tenure is lower, especially for men. Only East-German women do not differ by tenure and past unemployment spells. Also other personal characteristics, like the marital status or the age of the youngest child, vary with the number of working hours. Again, the effects differ by gender. While part-time working men are less likely to be married and have younger kids, the opposite holds for women. Interestingly, Hirsch (2005) reveals the same result with respect to the marital status for the US. These findings lead to the supposition that part-timers not only differ with respect to the list of currently observable variables, but also in many unobservable characteristics, complicating the identification of causal effects of working hours on wage rates.

\section{Empirical methods to approach the part-time wage gap}

Wage rates effect labour supply decisions and changes in working hours affect wage rates. Hence, the principle challenge in estimating the part-time pay penalty is to overcome this identification problem. Simple cross section regressions of hourly wage rates on the number of working hours suffer from potential endogeneity of the latter. If, for instance, one's individual earnings capacity is regarded as rather low, desired working hours is expected to be few - provided that labour supply is actually positively related to the wage rate. Furthermore, individuals with a strong commitment to the world of paid work and long-term ambitions make greater investments in their human capital, are better deployable in working teams and hence more valuable for a company than workers with erratic labour supply preferences. Finally, a potential measurement error in reported hours harms the exogeneity assumption of the part-time indicator, if the part-time status is derived from the reported number of working hours and hourly wage rates are calculated based on monthly/weekly earnings and working hours per month/week (Borjas 1980).

One way to handle these problems is to apply an instrumental variable approach that typically uses the number of small children in the household or other household characteristics as instruments for the working hour regime in the wage equation (see e.g. Manning and Petrongolo 2008 as well as Wilson 2010). If the presence of children reduces women's labour supply without affecting their productivity, this approach yields consistent results. If, however, child caring responsibilities do limit individual productivity or restrict one's job opportunities (because some jobs request exceptional flexibility and cannot be organised by employees with reduced hours), the resulting wage effects overestimate the true wage gap due to reduced working hours. Another way to accommodate the 
endogeneity of working hours is to estimate a simultaneous model of labour supply and wage rates. Again, the identification of the effect of hours on wages relies on the goodness of the exclusion restriction. While there exist some applications for women (see e.g. Browning 1992 or Wolf 2002), this strategy risks to fail in the case of men, because it is rather difficult to find adequate instruments for men's working hours. The third strategy which can be applied with cross section data is a two-step estimator where the correction term in the wage equation (potentially one for each labour supply regime) results from a (ordered) probit model of labour supply (see e.g. Hardoy and Schøne 2006). However, this approach also requires appropriate exclusion restrictions in the labour supply equation which are not obvious for men.

In this empirical analysis, I investigate the impact of part-time work on wage rates for both, men and women, and therefore refrain from searching for instrumental variables and exclusion restrictions. Instead, I use the panel structure of the SOEP to identify the wage effects of reduced working hours. Equation (A) describes the standard log-linear wage equation:

(A) $\ln W_{i t}=\alpha+X_{i t} \beta+\delta P T_{i t}+\Phi_{i}+\mu_{i t}$,

(B) $\ln W_{i t}=\alpha+X_{i t} \beta+\delta_{1} M E_{i t}+\delta_{2} P T S_{i t}+\Phi_{i}+\mu_{i t}$

The dependent variable $\ln W_{i t}$ is the log of gross hourly wages of an employed individual $i$ in year $t$. $X_{i t}$ is a vector of explanatory variables including individual and job-specific characteristics and $\beta$ the corresponding vector of coefficients. $\alpha$ denotes the constant term. $P T_{i t}$ represents a dummy variable equal to one if employee $i$ works part-time and $\delta$ measure the resulting wage effect. To limit the negative correlation between the part-time status and the hourly wage rate in case of measurement errors (Borjas, 1980), I use the self-assessment to classify respondents into part-time and full-time employees. Since part-time jobs differ with respect to taxation and the obligation to contribute to social security, Equation (B) differentiates between marginal employees $\left(M E_{i t}\right)$ and employees with reduced working hours who are fully subject to social security contributions $\left(P T S_{i t}\right)$. The unexplained part of observed wage rate can be separated into an individual specific fixed effect $\Phi_{i}$ and the random error term $\mu_{i t}$ with mean zero and constant variance. Since the individual fixed effect may be correlated with the part-time status but cannot be observed, $\delta$ (as well as $\delta_{1}$ and $\delta_{2}$ ) may suffer from the omitted variables bias.

First, I run OLS regressions separately for all four groups of individuals in 2010. To limit the bias due to unobserved characteristics, I include as much information as available about the individual's current labour market characteristics and labour market history. If unobservable individual characteristics correlate with the current working time schedule, this should also hold for past part-time spells. I hence follow Hirsch (2005) and use the comprehensive information on the employment history to capture large parts of these unmeasured worker attributes. Limited motivation or a disposition to shirk, for instance, may cause lower 
individual wages but also affect past employment history and the present working hours scheme. Adding past part-time periods or unemployment spells to the wage equation reduces the potential correlation between the error term, the individual fixed effect and the estimated coefficient of the binary part-time variable. As a result, the wage effect for current part-time employment should diminish. Apart from accounting for the labour market history, supplementary information on employers and employees is added step by step in order to better encompass unobserved individual productivity.

But still, individual fixed effects may remain in the error term. In a second step, I therefore run fixed-effect panel estimates of equation (A). This ensures that time-constant fixed effects do not bias the coefficient of the part-time indicator variables. Using fixed-effects models is no panacea, though. First, sufficient individuals switching their working hours are required in order to determine the wage effects of working hours with statistical significance. Second, measurement errors magnify the attenuation bias caused by calculated hourly wage rates (Borjas 1980). And third, this approach assumes symmetric effects of reducing and increasing labour supply. According to (Hirsch 2005), longitudinal estimates without considering selection into the labour force approximate the average treatment effect among the treated. Again, I estimate various specifications with different sets of explanatory variables for each group of individuals.

Finally, I investigate the time trend in the wage effects of working hours over the whole observation period. Starting with year-by-year OLS wage regressions, I present part-time wage gaps by year. Second, I interact a trend variable with the different working time indicators. The coefficients of these interaction terms indicate whether the part-time pay penalty changed during my observation period or not. Again, I run cross-section as well as panel estimates to eliminate the effect of unobserved characteristics step-by-step.

\section{Results}

The presentation of the estimation results is reduced to the different part-time variables and their standard errors. ${ }^{3}$ All numbers represent percentaged wage cuts of employees with reduced working hours relative to standard full-time employees.

\subsection{Cross section estimates}

Table 2 presents the cross section estimation for the year 2010. The coefficients of the selfreported part-time status $P T_{i 2010}$ are reported in Panel A. The set of variables that should be controlled for in order to obtain a reliable estimate of the wage gap is not obvious, because some of the explanatory variables are not exogenous but correlate with the part-time status due to the limited choice of job offers for part-timers (see e.g. Manning and Petrongolo 2008). I therefore present six specifications adding individual and firm characteristics step by

\footnotetext{
${ }^{3}$ The estimated coefficients of all other explanatory variables are omitted for reasons of clarity. The estimation results of all specifications are available on demand.
} 
step. The estimated coefficients of the respective working-hours variables in equation $A$ and $B$ are transformed into percentage wage cuts for reduced working hours relative to full-time employment, the so-called part-time wage gap. The reported t-values refer to the corresponding coefficients. Negative and statistical significant wage gaps are shaded grey.

The wage gap of the first specification represents the raw (or observed) part-time wage differential, as the part-time dummy is the only explanatory variable. For West German men, the wage cut amounts to 41 percent and is higher than for any other group. East German employees with reduced working hours exhibit lower wage cuts on average, but again, the part-time penalty for men is twice as high as for women. In the next step, I add four indicator variables on qualification levels, actual work experience (in years) and its square and firm tenure (in years) to account for differences in human capital endowment between full-time and part-time employees. The wage cuts shrink by 4 to 6 percentage points, but are still significant for all groups.

Instead of actual experience, Specification 3 uses separate variables for experience (in years) in full-time and part-time employment as well as unemployment and its squares. Unobserved individual characteristics which correlate with the current labour market status may partly be captured by these work history variables, such that the potential bias in the wage effect of working hours should be reduced (Hirsch 2005). In fact, the resulting wage gap for West-German men shrinks again by 6.6 percentage points and also the wage cut among the other groups diminish by 3 to 5 percentage points. Wages rates of East German part-time women do no more differ significantly from full-time wages. The regional and gender differences of the part-time penalty remain the same, though.

It is interesting to note, that the number of years in part-time work have no significant positive effect on the future wage profile for neither group. ${ }^{4}$ Even though, past part-time spells cause additional wage cuts due to missing full-time experience. In my specification, the effect of past part-time work strongly depends on the duration of part-time experience. This result is consistent with the findings of Beblo und Wolf (2002) who estimate a positive rate of depreciation of human capital during part-time employment of West German women and Fernandez-Kranz et al. (2012) who use a trivariate random effects model to identify lower returns to experience in part-time employment hinting at substantial negative longterm wage effects of female part-time employment in Spain. Russo and Hassink (2008) show that the number of working hours indirectly affects wage growth via a reduced likelihood of promotions in the Netherlands. In that case, part-time wage cuts are rather persistent, because they cannot immediately be cured by just increasing the number of working hours. This finding hence supports Hirsch's (2005) conclusion that prior part-time status has a far larger impact than does current status on the observed current wage.

Specification 4 adds several firm characteristics to the wage equation, which are 10 indicator variables for industry sectors, one for the public sector and three firm size dummies. The

\footnotetext{
${ }^{4}$ The number of years in unemployment exhibits the expected negative effect on future wage rates for all groups.
} 
inclusion of these variables has rather small effects on the estimated wage gaps compared to the former steps. This indicates that the selection of part-time employees into low paying sectors (especially the service sector) and smaller firms - often characterized by a lower degree of specialization and work sharing increasing the frictional costs of part-time work does not "explain" much of the wage differentials between part-time and full-time employees. Provided that West German part-time women worked in the same distribution of firms as full-time employed women, the part-time wage gap would shrink by three percentage points, which is the largest effect among the four groups of individuals. The wage gap for part-time working men resulting from this specification is hence still larger than for women.

Table 2: Wage level estimates of the part-time wage gaps in 2010 (in percent)

\begin{tabular}{|c|c|c|c|c|c|c|c|c|}
\hline & \multicolumn{4}{|c|}{ West Germany } & \multicolumn{4}{|c|}{ East Germany } \\
\hline & \multicolumn{2}{|c|}{ Men } & \multicolumn{2}{|c|}{ Women } & \multicolumn{2}{|c|}{ Men } & \multicolumn{2}{|c|}{ Women } \\
\hline & gap & t-val. & gap & t-val. & gap & t-val. & gap & t-val. \\
\hline \multicolumn{9}{|l|}{ A Self-reported part-time employment } \\
\hline 1. No control variables & $-41,2$ & $-14,9$ & $-21,1$ & $-13,5$ & $-29,9$ & $-4,9$ & $-15,0$ & $-4,7$ \\
\hline 2. ... plus human capital variables & $-36,0$ & $-14,9$ & $-17,5$ & $-12,2$ & $-24,5$ & $-4,6$ & $-8,9$ & $-3,2$ \\
\hline 3. ... plus detailed work history & $-29,4$ & $-10,6$ & $-12,3$ & $-6,7$ & $-21,3$ & $-3,5$ & $-4,7$ & $-1,4$ \\
\hline 4. ... plus firm characteristics & $-27,2$ & $-9,9$ & $-9,2$ & $-5,1$ & $-19,7$ & $-3,4$ & $-5,1$ & $-1,6$ \\
\hline $\begin{array}{l}\text { 5. ... plus job characteristics } \\
\text { (occupation, fixed term-contract) }\end{array}$ & $-20,8$ & $-7,6$ & $-4,4$ & $-2,5$ & $-14,9$ & $-2,6$ & $-2,4$ & $-0,8$ \\
\hline 6. ... plus personal characteristics & $-20,8$ & $-7,6$ & $-6,2$ & $-3,4$ & $-14,8$ & $-2,6$ & $-3,6$ & $-1,2$ \\
\hline \multicolumn{9}{|c|}{ B Self-reported part-time and marginal employment } \\
\hline \multicolumn{9}{|l|}{ Specification 1 (no control variables) } \\
\hline Marginal employment & $-53,0$ & $-14,4$ & $-45,4$ & $-22,8$ & $-47,3$ & $-5,3$ & $-53,0$ & $-9,8$ \\
\hline Part-time employment & $-29,7$ & $-7,6$ & $-11,9$ & $-7,1$ & $-19,1$ & $-2,4$ & $-7,7$ & $-2,3$ \\
\hline \multicolumn{9}{|l|}{ Specification 3} \\
\hline Marginal employment & $-38,1$ & $-10,6$ & $-33,8$ & $-15,5$ & $-25,4$ & $-2,7$ & $-35,2$ & $-6,2$ \\
\hline Part-time employment & $-21,1$ & $-5,7$ & $-4,5$ & $-2,3$ & $-19,2$ & $-2,7$ & 0,1 & 0,0 \\
\hline \multicolumn{9}{|l|}{ Specification 4} \\
\hline Marginal employment & $-36,0$ & $-10,2$ & $-28,3$ & $-12,7$ & $-22,2$ & $-2,5$ & $-31,9$ & $-5,8$ \\
\hline Part-time employment & $-18,8$ & $-5,1$ & $-2,9$ & $-1,6$ & $-18,4$ & $-2,7$ & $-1,1$ & $-0,3$ \\
\hline \multicolumn{9}{|l|}{ Specification 6 (full controls) } \\
\hline Marginal employment & $-26,6$ & $-7,2$ & $-22,7$ & $-9,9$ & $-17,6$ & $-2,0$ & $-24,6$ & $-4,5$ \\
\hline Part-time employment & $-16,0$ & $-4,5$ & $-1,4$ & $-0,8$ & $-13,5$ & $-2,0$ & $-0,5$ & $-0,2$ \\
\hline $\begin{array}{l}\text { Number of observations: } \\
\text { total (part-time) }\end{array}$ & \multicolumn{2}{|c|}{$2781(163)$} & \multicolumn{2}{|c|}{$2875(1561)$} & \multicolumn{2}{|c|}{$826(54)$} & \multicolumn{2}{|c|}{$868(335)$} \\
\hline
\end{tabular}

Note: Specification 2 adds four qualification level indicator variables, actual work experience (in years) and its square and firm tenure (in years). Instead of actual experience, Specification 3 uses separate variables for experience (in years) in full-time and part-time employment as well as unemployment and its squares. Specification 4 adds 10 indicator variables for industry sectors, one for the public sector and three firm size dummies. Specification 5 further controls for seven occupational groups and fixed-term contracts and Specification 6 adds the age of the youngest child in the household and two binary variables for Germans and being married.

Source: SOEP 2010. 
Specification 5 further controls for seven occupational groups and fixed-term contracts. Changes in the resulting part-time wage gap are huge and can be interpreted as an effect of occupational segregation in part-time employment. The wage cut for West-German parttime working men shrinks by 6.4 percentage points and now amounts to almost 21 percent, followed by East German men with a corresponding wage cut of almost 15 percent. West German women are subject to 4.4 percent wage reduction for part-time employment. Only the wage rates of East-German women do not seem to be affected by individual job characteristics. Note, however, that adding occupations and the type of contract to the list of explanatory variables presumes that these characteristics are randomly distributed and likewise available for all part-time and full-time employees. While this assumption may hold for a bunch of occupations, it is a stylized fact that some jobs are reserved to full-time employees. Whether specification 5 or specification 4 is more appropriate to measure the wage cut people have to expect when working reduced hours is not straightforward. Specification 4 can hence be interpreted as the pay penalty considering the limited job opportunities, part-time employees are subject to and is used as one of the benchmark models in the following analyses.

The inclusion of family related and individual characteristics - specification 6 adds the age of the youngest child in the household and two binary variables for Germans and being married - has no effect for men, but increases the estimated part-time gap among West German women. This implies that part-time wage cuts cannot be ascribed to the reduced productivity and flexibility of stressed women caring for a small child.

Summing up, I conclude that differences in human capital (qualification levels) have the strongest impact on the part-time pay penalty in East Germany. While the inclusion of these indicator variables also reduces the estimated wage gap by several percentage points in West Germany ${ }^{5}$, detailed work history information, i.e. employment breaks and unemployment spells, provides the largest contribution to understand the wage structure. Part-time employment does not only have a negative short-term effect, but depreciates future wage rates due to missing full-time experience. This is especially true for men. Almost equally important is the unequal distribution of occupations and permanent jobs among part- and full-time employees. Segregation among West German men yields pay penalty for part-timers of more than 6 percentage points, the corresponding figure for West German women and East German men amounts to about 5 percentage points.

Since the groups of self-reported part-time employees also include marginal employees, one may suppose that these findings are driven by the specifics of marginal employment. I therefore distinguish between regular part-time and marginal employment in the next step. Panel B in Table 2 illustrates the estimation results of selected specifications.

\footnotetext{
${ }^{5}$ The smallest effect of adding human capital variables on the part-time pay penalty is observed for West German women. This indicates that the diffusion of part-time work in all qualification levels is most advanced in this group, but there still exist differences in the part-time share among low and high skilled women.
} 
As expected, the raw wage gap differs tremendously between marginal and standard parttime employment. Interestingly, the raw wage cut compared to full-time employees is very similar for all four groups and amounts to between 45 and 53 per cent (see specification 1). Standard part-timers also earn significantly lower wages than full-time employees, nonetheless the gap is much smaller. The stepwise inclusion of additional worker and employer attributes reduced the wage cut for marginal employees by at least 50 per cent. But still, all marginal employment dummies are significant in the specification with all control variables. In contrast, the part-time wage gap in specification 6 is only significant for men. As expected, it is smaller than in Model A and amounts to 16 per cent in West Germany and 13.5 per cent in East Germany. Women's wage cut for part-time work turn insignificant once the work history (East Germany) or the firm characteristics are taken into account. That is, the estimated wage cut for West German part-time employees in Model A is strongly driven by the specifics of marginal employment. It is interesting to note that it is not only the second-earner wife, who is subject to notable wage cuts, but also men. This result corresponds to previous findings by Voss and Weinkopf (2012) and leads one to suppose that differences in the non-wage labour costs may trigger the moderate wage offers for marginal employees.

\subsection{Panel estimates}

Even if the vast information on labour market history and individual characteristics relevant on the labour market seem to limit the overestimation of the part-time wage gap, exploiting the panel structure is the mandatory next step. Fixed effect estimates ensure that timeconstant worker attributes do not bias the coefficient of the part-time indicator variables. The Hausman test clearly indicates that the null hypothesis can be rejected in all six specifications and all groups. Given the correlation between the unique errors and the regressors, I only present the results of the fixed effects equations A and B (see Section 4) in Table 3. In contrast to the cross section results, these figures represent the percentage wage effect of employees shifting between part-time and full-time employment. Upward and downward adoptions of working hours are assumed to have symmetric effects.

A first look at the upper panel of Table 3 reveals that the wage reductions for reduced working hours are lower compared to the cross-section estimates. This implies that unobserved worker attributes affecting the earnings potential are not entirely captured by accounting for the employment history and other individual and job characteristics. In fact, part-time employees seem to exhibit detrimental modes of behaviour, because part of the "unexplained" wage gap presented in Table 2 can be ascribed to the fixed effects. Nonetheless, men still suffer from severe wage cuts once they reduce their working hours. The average treatment-of-the-treated effect amounts to almost 17 percent in West Germany and 14 percent in East Germany. The inclusion of additional explanatory variables reduces the resulting part-time wage cut step by step. The richest model (specification 6) yields a wage differential of about 10 percent in both regions. Again, accounting of differences in human capital (specification 2) imposes a large drop in the estimated wage gap (2.6\% in West and $2.9 \%$ in East Germany). In contrast to the cross section results, the 
inclusion of job characteristics (specification 5) reduces the part-time wage cut for men, but the effect is not as large. On candidate explanation for this finding may be that the unobserved characteristics correlate with the occupations, such that the segregation effect is already captured by the unobserved characteristics in the fixed effects model to some extent.

Women's wage rates rely less on the number of working hours. Once the detailed work history is taken into account (specification 3), negative effects of reducing working hours can no more be detected. That is, the results show no indication for discrimination, because the observed wage cuts for part-time working women can fully be ascribed to observed and time-constant unobserved characteristics. This result is in line with the finding of Paul (2012) for West German women. In East Germany, part-time women even earn slightly higher wages than full-time working colleagues.

Table 3: Fixed effect estimates of the part-time wage gaps (1984-2010)

\begin{tabular}{|c|c|c|c|c|c|c|c|c|}
\hline & \multicolumn{4}{|c|}{ West Germany } & \multicolumn{4}{|c|}{ East Germany } \\
\hline & \multicolumn{2}{|c|}{ Men } & \multicolumn{2}{|c|}{ Women } & \multicolumn{2}{|c|}{ Men } & \multicolumn{2}{|c|}{ Women } \\
\hline & gap & t-val. & gap & t-val. & gap & t-val. & gap & $\mathrm{t}$-val. \\
\hline \multicolumn{9}{|c|}{ A Self-reported part-time employment } \\
\hline 1. No control variables & $-16,7$ & $-27,5$ & $-1,4$ & $-3,4$ & $-14,1$ & $-10,1$ & $-0,4$ & $-0,7$ \\
\hline 2. ... plus human capital variables & $-14,5$ & $-23,9$ & $-1,3$ & $-3,1$ & $-11,1$ & $-7,9$ & 0,8 & 1,3 \\
\hline 3. ... plus detailed work history & $-13,1$ & $-21,4$ & $-0,6$ & $-1,4$ & $-11,0$ & $-7,8$ & 0,9 & 1,4 \\
\hline 4. ... plus firm characteristics & $-12,3$ & $-20,1$ & 0,2 & 0,5 & $-10,7$ & $-7,5$ & 1,2 & 1,8 \\
\hline $\begin{array}{l}\text { 5. ... plus job characteristics } \\
\text { (occupation, fixed term-contract) }\end{array}$ & $-10,7$ & $-17,3$ & 0,8 & 2,0 & $-9,5$ & $-6,6$ & 1,6 & 2,4 \\
\hline 6. ... plus personal characteristics & $-10,6$ & $-17,1$ & 0,6 & 1,4 & $-9,5$ & $-6,6$ & 1,6 & 2,4 \\
\hline \multicolumn{9}{|c|}{ B Self-reported part-time and marginal employment } \\
\hline \multicolumn{9}{|l|}{ Specification 1 (no control variables) } \\
\hline Marginal employment & $-26,2$ & $-29,4$ & $-12,6$ & $-20,7$ & $-24,7$ & $-11,0$ & $-20,5$ & $-14,4$ \\
\hline Part-time employment & $-11,9$ & $-16,6$ & 0,6 & 1,5 & $-9,5$ & $-5,8$ & 1,7 & 2,5 \\
\hline \multicolumn{9}{|l|}{ Specification 3} \\
\hline Marginal employment & $-21,7$ & $-24,1$ & $-11,5$ & $-18,5$ & $-18,9$ & $-8,2$ & $-15,4$ & $-10,5$ \\
\hline Part-time employment & $-8,9$ & $-12,5$ & 1,2 & 2.9 & $-7,6$ & $-4,6$ & 2,8 & 4,1 \\
\hline \multicolumn{9}{|l|}{ Specification 4} \\
\hline Marginal employment & $-20,4$ & $-22,5$ & $-9,9$ & $-15,7$ & $-18,2$ & $-7,9$ & $-14,0$ & -9.5 \\
\hline Part-time employment & $-8,4$ & $-11,8$ & 1,8 & 4,2 & $-7,5$ & $-4,6$ & 2,7 & 4,0 \\
\hline \multicolumn{9}{|l|}{ Specification 6 (full controls) } \\
\hline Marginal employment & $-18,7$ & $-20,4$ & $-9,2$ & $-14,4$ & $-17,0$ & $-7,3$ & $-13,0$ & $-8,7$ \\
\hline Part-time employment & $-6,7$ & $-9,3$ & 2,0 & 4,7 & $-6,3$ & $-3,8$ & 3,0 & 4,5 \\
\hline $\begin{array}{l}\text { No. of observations: } \\
\text { total (part-time) }\end{array}$ & \multicolumn{2}{|c|}{$\begin{array}{l}80234 \\
(2590)\end{array}$} & \multicolumn{2}{|c|}{$\begin{array}{c}63437 \\
(28509) \\
\end{array}$} & \multicolumn{2}{|c|}{$\begin{array}{l}19584 \\
(626) \\
\end{array}$} & \multicolumn{2}{|c|}{$\begin{array}{l}19521 \\
(5547) \\
\end{array}$} \\
\hline
\end{tabular}

Note: see Table 2.

Also the results of Panel B show that eliminating time-constant but unobserved effects reduce the size of the estimated wage gaps, but do not change the main conclusions. Marginal jobs are paid significantly worse than full-time jobs and standard part-time jobs, 
irrespective from regional and gender differences. A rather surprising result is that women working part-time and covered with social security seem to earn slightly higher wages than their full-time colleagues. Furthermore, this premium is not really affected by the list of explanatory variables and amounts to 2 percent in West and 3 percent in East Germany. Candidate explanations for this finding are discussed in the conclusions.

\subsection{Sensitivity analysis}

As mentioned in section 3, the definition of the dependent variable is of crucial importance for analysing the link between working hours and wage rates. Since the hourly wage variable occasionally suffers from inaccurate or missing information on the relevant working hours, I created an auxiliary variable indicating that overtime hours are either paid or not compensated at all or agreed hours are missing. ${ }^{6}$ Even if this peculiarity does not specifically affect the hourly wage rates of part-time employees, it may bias the estimated wage gap between part-time and full-time employees (including all over-time-employees). ${ }^{7}$

Table 4: Cross section and fixed effect estimates with hours correction term (1984-2010)

\begin{tabular}{|l|c|c|c|c|c|c|c|c|}
\hline & \multicolumn{3}{|c|}{ West Germany } & \multicolumn{3}{c|}{ East Germany } \\
\hline & \multicolumn{2}{|c|}{ Men } & \multicolumn{2}{c|}{ Women } & \multicolumn{2}{c|}{ Men } & \multicolumn{2}{c|}{ Women } \\
\hline & gap & t-val. & gap & t-val. & gap & t-val. & gap & t-val. \\
\hline A Cross-section estimates (2010) & & & & & & & \\
\hline 1. No control variables & $-41,2$ & $-14,9$ & $-21,1$ & $-13,6$ & $-29,9$ & $-4,9$ & $-15,0$ & $-4,7$ \\
\hline 2. ... plus human capital variables & $-35,9$ & $-14,9$ & $-17,4$ & $-12,3$ & $-24,9$ & $-4,7$ & $-8,6$ & $-3,1$ \\
\hline 3. ... plus detailed work history & $-29,1$ & $-10,5$ & $-12,3$ & $-6,8$ & $-21,8$ & $-3,6$ & $-4,7$ & $-1,4$ \\
\hline 4. ... plus firm characteristics & $-27,0$ & $-9,9$ & $-9,3$ & $-5,2$ & $-19,9$ & $-3,4$ & $-5,0$ & $-1,6$ \\
\hline $\begin{array}{l}\text { 5. ... plus job characteristics } \\
\text { (occupation, fixed term-contract) }\end{array}$ & $-20,3$ & $-7,4$ & $-4,5$ & $-2,6$ & $-15,0$ & $-2,6$ & $-2,4$ & $-0,8$ \\
\hline 6. ... plus personal characteristics & $-20,3$ & $-7,4$ & $-6,1$ & $-3,4$ & $-15,0$ & $-2,6$ & $-3,5$ & $-1,2$ \\
\hline No. of observations & \multicolumn{2}{|c|}{2781} & & & & & \\
\hline
\end{tabular}

Note: see Table 2. Shaded cells indicate significant (5\%-level) negative wage gaps of part-time employment.

\footnotetext{
${ }^{6}$ In these cases, I use last month's actual working hours to construct hourly wage rates, which may, however, not be consistent with the last month's salary. Overtime hours within a flextime wage record cause no problems, because hourly wages are constructed based on contracted hours in that case (see section 0 ).

${ }^{7}$ In my sample, the share of employees that are concerned with paid or uncompensated overtime hours does not differ between part-time and full-time employees, but full-time employees work much more overtime hours on average.
} 
The coefficient of the auxiliary dummy variable turns out to be significantly negative in all specifications. That is, paid or uncompensated working hours are linked to lower hourly wage rates on average. Even though, the inclusion of the hours correction term does not really alter the results, so I only present cross-section and panel estimates of equation $A$ (see Table 4). In fact, the wage cut for working reduced hours is hardly affected by the inclusion of the hours correction term, neither in the cross section model nor in the fixed effects model.

Since part-time employment at the beginning and the end of the working career may be concerned with a number of particularities (holiday jobs, additional income of retired people), I secondly test whether the results change, if the lower and the upper tail of the age distribution are excluded from the sample.

While the male part-time wage gap in West Germany increases once I only consider the core age groups, both the size and the significance of the wage cuts for all other groups rather shrinks (see Table 5). In the end, only West German men exhibit a significant drawback from working reduced hours after controlling for all observable characteristics. Given the different wage effects of standard part-time and marginal jobs (see Table 3), this shift in the results may be caused by differences in the age structure of part-time and marginal employees.

Table 5: Wage level estimates of the part-time wage gap based on core age group in 2010

\begin{tabular}{|c|c|c|c|c|c|c|c|c|}
\hline & \multicolumn{4}{|c|}{ West Germany } & \multicolumn{4}{|c|}{ East Germany } \\
\hline & \multicolumn{2}{|c|}{ Men } & \multicolumn{2}{|c|}{ Women } & \multicolumn{2}{|c|}{ Men } & \multicolumn{2}{|c|}{ Women } \\
\hline & Gap & t-val. & gap & t-val. & gap & t-val. & gap & t-val. \\
\hline \multicolumn{9}{|l|}{ A Cross-section estimates (2010) } \\
\hline 1. No control variables & $-42,6$ & $-13,4$ & $-20,0$ & $-11,8$ & $-26,3$ & $-3,5$ & $-14,3$ & $-4,2$ \\
\hline 2. ... plus human capital variables & $-38,1$ & $-13,6$ & $-14,4$ & $-9,1$ & $-22,4$ & $-3,4$ & $-7,9$ & $-2,6$ \\
\hline 3. ... plus detailed work history & $-30,0$ & $-9,2$ & $-8,0$ & $-4,0$ & $-14,8$ & $-1,9$ & $-4,4$ & $-1,2$ \\
\hline 4. ... plus firm characteristics & $-26,6$ & $-8,3$ & $-5,5$ & $-2,8$ & $-9,8$ & $-1,3$ & $-4,1$ & $-1,2$ \\
\hline $\begin{array}{l}\text { 5. ... plus job characteristics } \\
\text { (occupation, fixed term-contract) }\end{array}$ & $-21,2$ & $-6,6$ & $-1,2$ & $-0,7$ & $-6,5$ & $-0,9$ & $-1,9$ & $-0,6$ \\
\hline 6. ... plus personal characteristics & $-21,2$ & $-6,7$ & $-2,4$ & $-1,2$ & $-5,0$ & $-0,7$ & $-3,0$ & $-0,9$ \\
\hline No. of observations & \multicolumn{2}{|c|}{2343} & \multicolumn{2}{|c|}{2392} & \multicolumn{2}{|c|}{668} & \multicolumn{2}{|c|}{723} \\
\hline \multicolumn{9}{|l|}{ A Panel estimates } \\
\hline 1. No control variables & $-14,4$ & $-21,1$ & $-1,4$ & $-3,2$ & $-11,5$ & $-7,3$ & 0,2 & 0,3 \\
\hline 2. ... plus human capital variables & $-13,0$ & $-19,1$ & $-0,4$ & $-0,9$ & $-8,3$ & $-5,3$ & 1,4 & 2,0 \\
\hline 3. ... plus detailed work history & $-11,7$ & $-17,0$ & 0,0 & 0,0 & $-8,8$ & $-5,5$ & 1,6 & 2,3 \\
\hline 4. ... plus firm characteristics & $-10,8$ & $-15,7$ & 0,8 & 1,8 & $-8,5$ & $-5,3$ & 1,8 & 2,7 \\
\hline $\begin{array}{l}\text { 5. ... plus job characteristics } \\
\text { (occupation, fixed term-contract) }\end{array}$ & $-9,3$ & $-13,5$ & 1,3 & 2,8 & $-7,7$ & $-4,8$ & 2,1 & 3,1 \\
\hline 6. ... plus personal characteristics & $-9,2$ & $-13,2$ & 1,1 & 2,5 & $-7,7$ & $-4,8$ & 2,2 & 3,2 \\
\hline No. of observations & \multicolumn{2}{|c|}{68021} & \multicolumn{2}{|c|}{53096} & \multicolumn{2}{|c|}{16783} & \multicolumn{2}{|c|}{16858} \\
\hline
\end{tabular}

Note: see Table 2. Employees are aged between 25 und 55 years. Shaded cells indicate significant (5\%-level) negative wage gaps of part-time employment. 
Table 6: Share of part-time and marginal employees by age group (in \%) in 2010

\begin{tabular}{|l|c|c|c|c|c|c|c|c|}
\hline & \multicolumn{3}{|c|}{ West Germany } & \multicolumn{5}{c|}{ East Germany } \\
\hline & \multicolumn{2}{|c|}{ Men } & \multicolumn{2}{|c|}{ Women } & \multicolumn{3}{c|}{ Men } & \multicolumn{2}{c|}{ Women } \\
\hline & PTS & ME & PTS & ME & PTS & ME & PTS & ME \\
\hline Age groups & & & & & & & & \\
\hline $20-24$ years & 2.8 & 22.0 & 15.4 & 30.2 & 9.1 & 10.9 & 6.7 & 16.7 \\
\hline $25-29$ years & 5.2 & 9.0 & 19.2 & 13.2 & 4.8 & 1.6 & 22.0 & 1.7 \\
\hline $30-34$ years & 4.5 & 3.1 & 24.6 & 9.3 & 4.3 & 0.0 & 33.0 & 6.8 \\
\hline $35-39$ years & 3.4 & 1.4 & 48.5 & 13.8 & 2.2 & 3.3 & 40.2 & 3.7 \\
\hline $40-44$ years & 2.3 & 0.2 & 50.7 & 12.1 & 3.6 & 2.7 & 42.5 & 3.0 \\
\hline $45-49$ years & 2.0 & 0.4 & 48.7 & 13.0 & 2.3 & 0.0 & 39.0 & 3.9 \\
\hline $50-54$ years & 2.2 & 1.2 & 48.1 & 9.1 & 6.0 & 2.0 & 26.9 & 3.4 \\
\hline $55-60$ years & 5.2 & 1.2 & 45.1 & 11.9 & 4.5 & 1.5 & 36.3 & 6.7 \\
\hline
\end{tabular}

Note: own calculations based on the sample defined in section 3 .

Source: SOEP 2010.

Table 6 therefore illustrates the share of standard part-time and marginal employees by age group. A uniform result is that marginal employment is much more common in the age group from 20 to 24 years than in any other age category. The exclusion of these observations therefore generates a reduction of the estimated wage gaps, which actually holds for all groups, except for West German men. They are subject to another peculiarity, namely partial retirement, though. The share of standard part-time employees among the West German men aged between 55 and 60 year amounts to 5.2 percent, which is twice as high as in most of the younger age groups. Part-time retirement is a labour market program supported by the German state and hence extremely regulated. Wage reductions in connection with these working hours reductions at the end of the career are therefore very unlikely. As a result, the exclusion of these part-timers tends to increase the estimated wage cut for reduced working hours.

Limiting the sample to the core age groups in the panel estimate of equation A slightly reduces the average wage cuts for all men reducing their number of working hours, which partly contravenes the cross-section results. The differences are small, though, and may be caused by heterogeneous unobserved characteristics.

\subsection{Time trend}

Contrary to most suppositions derived in Section 2, a first look on the yearly part-time wage gaps reveals that the penalty for working reduced hours seems to increase over time. Figure 2 shows the observed wage cuts of self-reported part-timers (specification 1 without any control variables) exploiting all available cross sections in East and West Germany. While there appears a clear negative time trend in West Germany, the yearly wage gaps are much more dispersed for East German men - presumably caused by the small number of observations) and rather stable for East German women. Interestingly, these figures bear significant resemblance to the observed part-time penalty in the UK (Manning and 
Petrongolo 2008). In a next step, I go through several specifications to test whether this result holds once observed and unobserved heterogeneity is accommodated.

Figure 2: Observed part-time wage gaps (1984-2010)

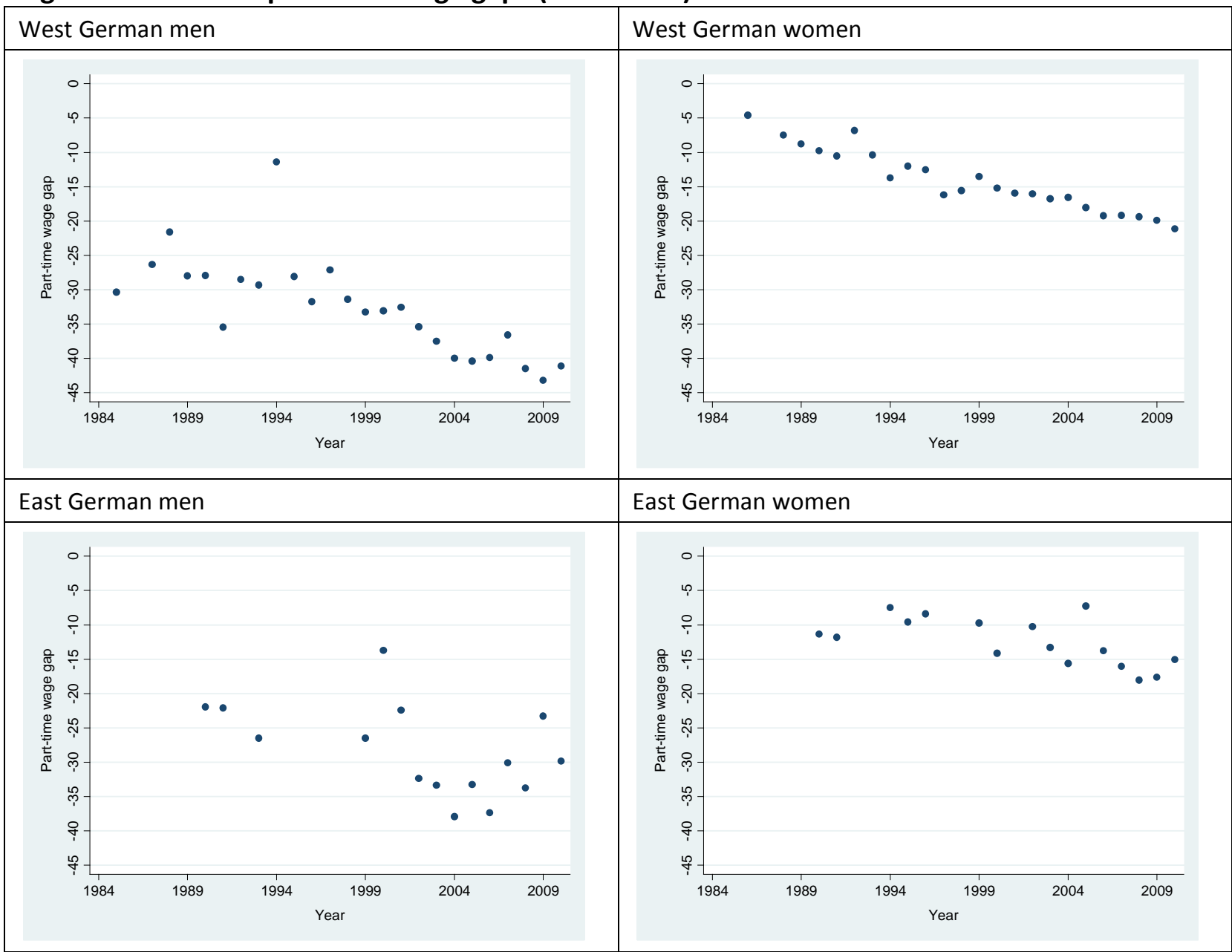

Note: Part-time wage gap based on the self-reported part-time status (equation A, specification 1, age group 20 -60 years old). Figures include only statistical significant results (5\%-level).

Source: SOEP 2010.

Figure 3 illustrates the time trend in part-time wage gaps based on pooled cross sections and fixed effects panel estimates. I restrict this analysis to specification 1 (as a benchmark) and specification 4. Apart from human capital variables, this specification only includes industry and firm size dummies - whose distributions have changed significantly during the long observation period due to structural changes in the economy. Additionally controlling for occupations (see specification 5) may absorb too much of the observed wage differences, because segregation is highly triggered by the availability of adequate part-time jobs. The results can therefore be interpreted as a human capital based proxy for the part-time wage gap. All markers represent the relative wage rate of part-timers compared to full-time employees (markers equal to one indicate equal wage rates). The time trend is estimated by the fifth polynomial of a linear time trend and its interactions with the part-time indicator $P T_{t}$ in order to capture nonlinear effects. 
The figure derived from the pooled cross section estimation of specification 1 more or less summaries the results from Figure 2. While West German part-timers as well as female parttime employees in East Germany exhibit increasing part-time penalties over time, male parttimers in East Germany do not follow a clear trend, which may partly be driven by a rather small number of observations (see Table 8 in the Appendix). Markers of the last observation period approximate the cross-section results presented in Table 2, respectively. The unexplained wage gaps resulting from the pooled cross section estimate of specification 4 are lower on average, but exhibit the same pattern as specification 1 . This implies that the observed differences in human capital endowment, work history and firm characteristics matter and account for a more or less constant amount of wage inequality.

Figure 3: Part-time wage gaps based on pooled cross sections and fixed effect estimation with non-linear trend- interactions (1984-2010)

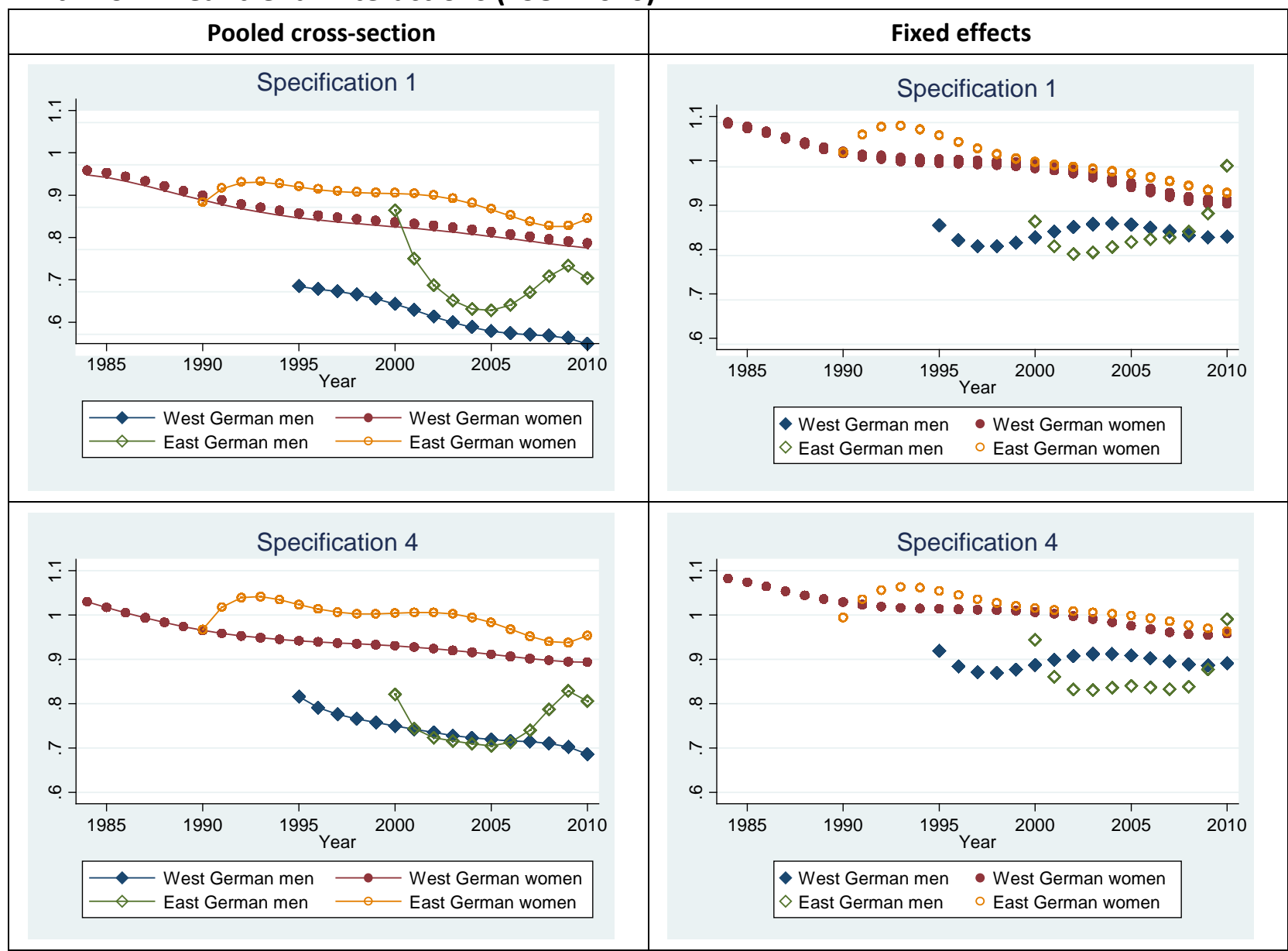

Note: All dots represent part-time wage cuts resulting from pooled cross-section or fixed effects estimates extended by a non-linear time trend (up to the fifth polynomial) and its interaction with the part-time dummy variable. The estimates are restricted to years, where the number of part-time employees exceeds 50 observations (respectively 30 observations for men in East Germany).

Separating individual fixed effects does not only yield an upward shift of relative part-time wages, but also reshapes their long-term trend. In principle, differences between the trend based on pooled cross section and fixed effects can be caused by changing selection effects into part-time employment or variations in the composition of part-time employees (marginal versus standard part-time employees). While the time trend is very similar and 
almost linear for women in both econometric approaches and all specifications (except the short upward trend of East German part-time wages in the early 1990s), the change in the relative wage rate of West German part-time working men seem to be affected by compositional effects. The flattening of the trend for West German men implies that part of the ongoing decline in relative remuneration of male part-time employees, illustrated in the left panel of Figure 3, is caused by an adverse selection into jobs with reduced working hours. The differences between specification 1 and 4 are marginal, hinting at a considerable correlation between the unobserved characteristics and the observed human capital and industry variables. The individual loss caused by reducing the number of working hours amounts to about 10 percent for West German men, but seems to be rather constant over time (see specification 4). Women, in contrast, seem to have earned a surplus by reducing their working hours until the end of the last century. Nonetheless, the relative remuneration of female part-time employees degraded over time by more than 10 percentage points (see specification 4). The standard panel approach (see Table 3) hinting at nearly equal wages for part-time and full-time working women in West Germany hence conceals the downward trend in relative part-time wages.

To see whether this trend is driven by the extension of marginal employment (see Körner et al. 2013 or Destatis, 2014) ${ }^{8}$, I use equation B as the basic model and interact both, the parttime and the marginal-employment dummy with the fifth polynomial of the linear trend. Due to the limited number of marginal employees, I restrict this analysis to West Germany. Figure 4 presents the relative remuneration of marginal employees (MEWG) and standard part-time employees (PTWG) covered with social security based on pooled cross sections and fixed effects estimates. While the pooled cross section approach hints at deceasing relative wages of male and female marginal employees (specification 1 and 4), the fixed effects model yield a rather stable relative remuneration of marginal employed women once also observed characteristics are taken into account (specification 4). Women in jobs not covered with social security earned on average 80 percent of comparable full-time employees in 1990 and somewhat more than 70 percent in the year 2010 (see pooled cross section, specification 4). Presumably, these high wage gaps of marginal employees are driven by adverse selection into this type of atypical employment, because shifting to marginal employment (with constant observed and unobserved characteristics) only yields an average wage loss of about 10 percent (see the fixed effects model, specification 4). That is, the flattening of the negative trend in relative wages of marginal employees is consistent with the notion that more and more women with undesirable unobserved labour market characteristics select into marginal employment.

Apart from the fact that the tails of the trend in wage gaps for men not covered by social security are somewhat scraggy, Figure 4 also hints at a general downtrend. Differences between the cross section and the panel approach only concern the size, but not the shape

\footnotetext{
${ }^{8}$ Marginal employment continuously raised during the whole observation period. Changes in the legislation boosted this type of employment from time to time.
} 
of the time trend, implying that unfavourable unobserved characteristics prevent an equivalent remuneration of marginal employees. The increasing gap between marginal employees and their colleagues does not seem to be driven by adverse selection of men with unfavourable labour market characteristics into marginal employment, though. A look at the wage effects of standard part-time jobs (PTWG) reveals that individual losses from changing working hours seem to be stable over time. Again, the accommodation of observed and unobserved characteristics diminishes the wage differentials, but cannot rule out some kind of discrimination (see fixed effects panel).

The relative remuneration of standard part-time jobs of women lacks the overall downward trend visible in Figure 3. As soon as human capital and industry variables are taken into account, the female part-time wage gap melts away (see both specifications 4). That is, women in standard part-time jobs do not seem to be penalized, nonetheless long part-time spells impose a significant financial burden due to differences in the returns to experience. Based on the fixed effects model, West German women working part-time for at least 8 years of their 22 years in employment yield lower returns to experience compared to equivalent women continuously working full-time. ${ }^{9}$

So, how does the downtrend in relative wages of female part-timers shown in Figure 3 fit to the rather flat trends presented in Figure 4? One candidate explanation is that the rising wage penalty for working reduced hours results from an increasing share of marginal employees, who are subject to higher wage penalties. Analogue to the general trend, the share of marginal employees compared to the share of standard part-time employees among all West German women in our sample significantly increased during the observation period (see Table 8 in the appendix). This interpretation of the empirical results does not support the hypothesis that the status of marginal employees improved by the implementation of the Part-Time Work and Fixed-Term Employment Contract Law in 2001.

Interestingly, the differences between the pooled cross section and the fixed effects model are much larger for marginal employees than for part-time employees. Hence, unobserved characteristics are much more relevant to understand the wage setting for marginal employees. Part-time wage rates, however, are mainly determined by observable characteristics.

\footnotetext{
${ }^{9}$ This result strongly depends on the assumption concerning the total years in employment. As a benchmark, I use the average years of work experience of West German women (see Table 7 in the Appendix) to calculate the wage effect of past part-time spells. The negative wage effects increase, if a shorter career is shorter, though.
} 
Figure 4: Marginal employment and part-time wage gaps in West based on pooled cross sections (West Germany 1984-2010)

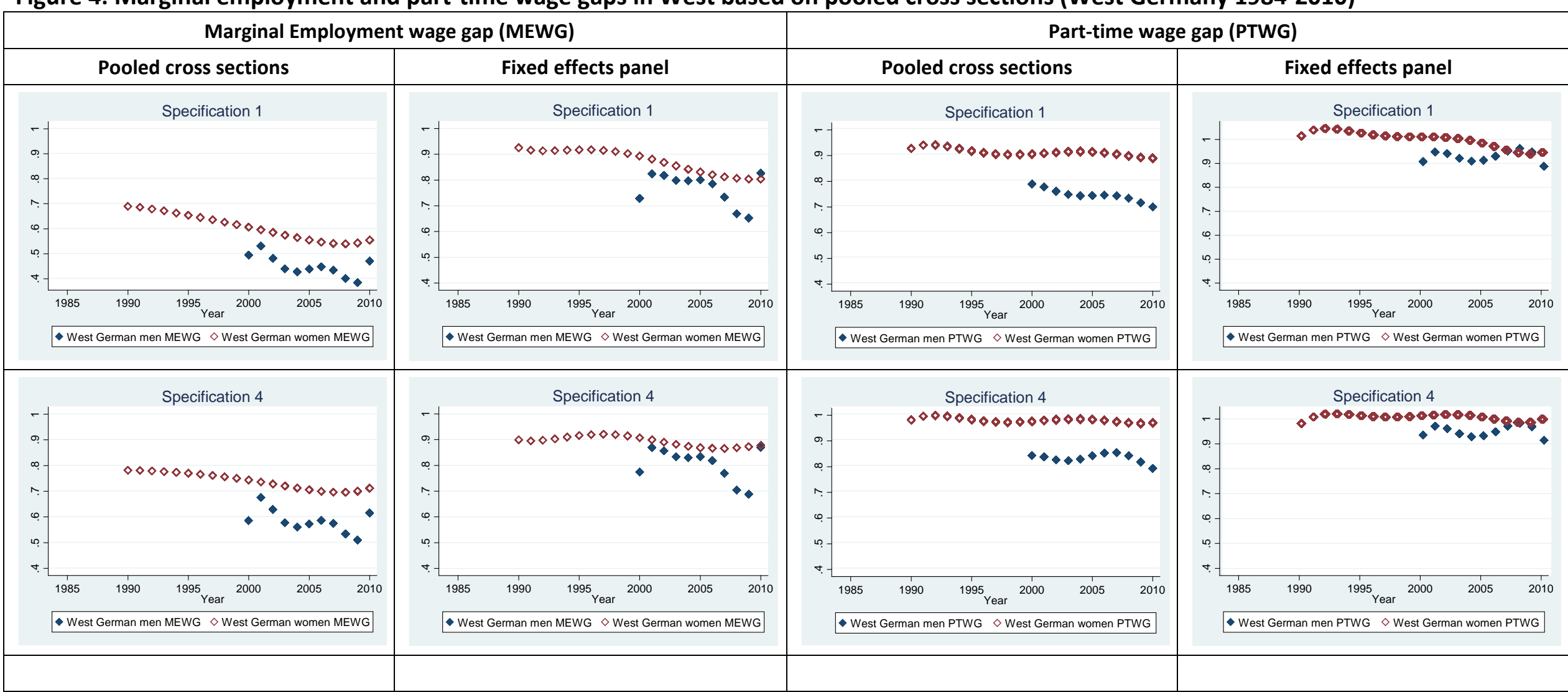

Note: All dots represent part-time wage cuts resulting from pooled cross section estimates extended by a non-linear time trend (up to the fifth polynomial) and its interaction with the part-time dummy variable. 


\section{Discussion and conclusions}

Despite the increasing incidence of part-time employment in Germany, the effects on wage rates are studied rarely. Especially, a comprehensive study analysing the long-term and short-term effects of reduced working hours of both, women and men in East and West Germany is missing. I therefore use SOEP panel data and apply different econometric approaches and definitions of part-time work to measure the so-called part-time wage gap.

My results indicate that men suffer most from wage cuts for working reduced hours. Observed wage differences between full-time and part-time working women melt away as soon as observed and unobserved characteristics are taken into account. Hence, there is no reason to suppose that reducing the number of working hours necessarily limits the earnings potential of women. Note, however, that long part-time spells in the work history generate no positive or even negative returns to experience. Financial disadvantages of part-time employment cannot be ruled out, though, especially if short working hours represent the predominant status in employment history.

Wage penalties are even larger, if women shift to marginal jobs. Ignoring the lower returns to experience, women shifting to marginal employment suffer from a 10 percent wage cut, on average. Note, however, that women shifting to a standard part-time job covered by social security even gained a slightly higher remuneration as for a comparable full-time job in some years. To interpret this result, I follow Booth and Wood (2008) and argue that parttime workers may be more productive for the time that they are at work, because they are more focused for a shorter time period each day. Technically speaking, they are located on the rising part of the hours-productivity profile. Furthermore, part-time women may be less concerned with unpaid overtime-hours, because they often work under strict time restrictions due to child-care responsibilities.

In contrast, the inclusion of extended information on individual characteristics as well as unobserved fixed effects quarters the raw part-time wage gap of men, but the differences between part-time and full-time wages are still significant and amount to 10.6 percent in West and 9.5 percent in East Germany. However, this wage cut covers the huge differences between standard part-time employment, where workers are covered with social security, and marginal employment, whose wage penalties are about three times higher. Marginal employed men earn 18.7 percent less than comparable full-time employees in West Germany ( 17 percent in East Germany), whereas part-time employed men only miss 6.7 percent of full-time wage rates in West Germany (6.3 percent in East Germany).

Robustness checks with respect to the definition of the hourly wage rate and the age group hardly alter the results. Interestingly, the gender differences with respect to the part-time wage gap are in line with previous results - not only for Germany (Behmer and Seifert 2008, Aaronson and French 2004, Wahlberg 2008a) and may be explained by a higher monopsony power of firms offering part-time positions for jobs and tasks where reduced working hours are still very rare. Empirical evidence on the link between monopsony power and part-time wage is missing, though, not only for Germany. 
Another novel of my study is the analysis of the time trend of the part-time wage gap. While there are good reasons to believe that the part-time wage gap shrinks over time, the empirical evidence reveals the opposite. Both, the raw wage gap as well as the wage gap resulting from an extended human capital wage equation reveal increasing wage penalties for part-time working women and men in West Germany. In light of the supposition that the wage penalty tends to be lower in times when part-time shares are higher and employers get accustomed to alternative working time schemes, this finding surprises. Since this trend disappears for men, as soon as individual fixed-effects are disentangled, I suppose that selection of men with more and more unfavourable labour market characteristics triggered this downward slope. More precisely, it turned out that especially marginal employment is concerned with this type of adverse selection. In contrast, the downtrend of the female parttime wage gap seems to be caused by the increasing share marginal employees, who exhibit a significant and larger wage cut compared to standard part-time women.

Manning and Petrongolo (2008) also show that the gap between part-time and full-time wages has widened greatly over the past 30 years in the UK. They argue that this trend in the pay penalty is partly a result of a rise in occupational segregation and partly the general rise in wage inequality.

What do these results imply for couples trying to share labour as well as the caring responsibly for their children? According to the survey "Families in Germany" (Schröder et al. 2012), this model represents the desired way of work sharing for 60 percent of the families whose youngest child is aged between 1 and 3 years. Therefore, a currently discusses reform of the parenting benefit is meant to support part-time employment of both parents (the socalled "Elterngeld PLUS"). My analysis shows that temporary reductions of working hours do not seem to cause a financial burden for women, though for men. In the long run, missing returns to part-time experience decelerates wage growth and hence sustainably aggravates the income potential of families practicing work sharing. In sum, families following the worksharing model are worse off compared to traditional (male) breadwinner households. Given the actual debate about skill shortage and male dominated management boards, the significant wage gaps for male part-time employees is bad news and should be considered by political decision makers. 


\section{Appendix}

Table 7: Means of all explanatory variables by working time regime (2010)

\begin{tabular}{|c|c|c|c|c|c|c|c|c|}
\hline \multirow[b]{3}{*}{ Variable } & \multicolumn{4}{|c|}{ West Germany } & \multicolumn{4}{|c|}{ East Germany } \\
\hline & \multicolumn{2}{|c|}{ Men } & \multicolumn{2}{|c|}{ Women } & \multicolumn{2}{|c|}{ Men } & \multicolumn{2}{|c|}{ Women } \\
\hline & $\mathrm{FT}^{1}$ & $\mathrm{PT}^{1}$ & $\mathrm{FT}^{1}$ & $\mathrm{PT}^{1}$ & $\mathrm{FT}^{1}$ & $\mathrm{PT}^{1}$ & $\mathrm{FT}^{1}$ & $\mathrm{PT}^{1}$ \\
\hline no vocational training & 0,10 & 0,16 & 0,11 & 0,14 & 0,05 & 0,07 & 0,02 & 0,03 \\
\hline vocational training & 0,54 & 0,32 & 0,57 & 0,62 & 0,63 & 0,51 & 0,52 & 0,67 \\
\hline master craftsman & 0,08 & 0,04 & 0,05 & 0,04 & 0,09 & 0,06 & 0,06 & 0,04 \\
\hline vocational training for civil & & & & & & & & \\
\hline servants & 0,03 & 0,00 & 0,02 & 0,01 & 0,02 & 0,00 & 0,01 & 0,01 \\
\hline university degree & 0,24 & 0,48 & 0,26 & 0,19 & 0,21 & 0,35 & 0,39 & 0,26 \\
\hline FT-experience (in years) & 19,30 & 9,53 & 14,36 & 7,65 & 19,15 & 8,94 & 16,83 & 13,27 \\
\hline PT-experience (in years) & 0,54 & 4,65 & 2,52 & 9,22 & 0,34 & 4,11 & 1,80 & 7,63 \\
\hline unemployment (in years) & 0,47 & 1,44 & 0,49 & 0,79 & 0,83 & 2,29 & 1,10 & 1,63 \\
\hline tenure & 12,97 & 6,36 & 10,62 & 8,75 & 10,74 & 5,31 & 10,72 & 10,99 \\
\hline public sector & 0,22 & 0,29 & 0,32 & 0,29 & 0,24 & 0,32 & 0,34 & 0,27 \\
\hline mining & 0,02 & 0,01 & 0,01 & 0,00 & 0,04 & 0,05 & 0,01 & 0,00 \\
\hline engineering, electronic and & & & & & & & & \\
\hline metalworking industry & 0,18 & 0,05 & 0,07 & 0,02 & 0,19 & 0,12 & 0,08 & 0,00 \\
\hline chemical industry & 0,07 & 0,03 & 0,07 & 0,03 & 0,04 & 0,10 & 0,02 & 0,01 \\
\hline construction & 0,08 & 0,02 & 0,02 & 0,01 & 0,12 & 0,02 & 0,02 & 0,01 \\
\hline iron, steel and heavy industry & 0,07 & 0,04 & 0,03 & 0,01 & 0,08 & 0,00 & 0,01 & 0,01 \\
\hline textile and food industry & 0,03 & 0,03 & 0,03 & 0,03 & 0,02 & 0,00 & 0,02 & 0,02 \\
\hline Whole sale and retail & 0,09 & 0,08 & 0,14 & 0,22 & 0,07 & 0,22 & 0,09 & 0,24 \\
\hline Rail, mail and transportation & 0,07 & 0,10 & 0,03 & 0,02 & 0,07 & 0,01 & 0,05 & 0,05 \\
\hline Public services & 0,22 & 0,41 & 0,41 & 0,46 & 0,21 & 0,32 & 0,53 & 0,51 \\
\hline Private services & 0,13 & 0,21 & 0,17 & 0,18 & 0,11 & 0,17 & 0,16 & 0,13 \\
\hline others & 0,04 & 0,02 & 0,02 & 0,01 & 0,04 & 0,00 & 0,01 & 0,01 \\
\hline$<20$ employees & 0,15 & 0,37 & 0,23 & 0,36 & 0,21 & 0,30 & 0,25 & 0,32 \\
\hline$\geq 20$ and $<200$ employees & 0,29 & 0,30 & 0,28 & 0,28 & 0,39 & 0,22 & 0,32 & 0,28 \\
\hline$\geq 200$ and $<2000$ employees & 0,25 & 0,18 & 0,24 & 0,19 & 0,21 & 0,35 & 0,26 & 0,16 \\
\hline$\geq 2000$ employees & 0,30 & 0,15 & 0,26 & 0,17 & 0,19 & 0,13 & 0,17 & 0,24 \\
\hline manager & 0,06 & 0,01 & 0,04 & 0,01 & 0,03 & 0,01 & 0,04 & 0,00 \\
\hline scientist & 0,19 & 0,19 & 0,19 & 0,11 & 0,12 & 0,17 & 0,17 & 0,14 \\
\hline engineer and equivalent & & & & & & & & \\
\hline nontechnical occupations & 0,21 & 0,10 & 0,34 & 0,26 & 0,19 & 0,06 & 0,42 & 0,38 \\
\hline commercial clerk & 0,09 & 0,06 & 0,19 & 0,16 & 0,06 & 0,06 & 0,13 & 0,13 \\
\hline sales clerk & 0,06 & 0,28 & 0,14 & 0,24 & 0,09 & 0,25 & 0,11 & 0,23 \\
\hline skilled worker & 0,21 & 0,13 & 0,03 & 0,03 & 0,28 & 0,04 & 0,04 & 0,02 \\
\hline machine operator & 0,14 & 0,10 & 0,04 & 0,02 & 0,15 & 0,12 & 0,04 & 0,03 \\
\hline unskilled worker & 0,06 & 0,13 & 0,03 & 0,16 & 0,07 & 0,29 & 0,04 & 0,06 \\
\hline temporary job & 0,06 & 0,21 & 0,09 & 0,14 & 0,08 & 0,34 & 0,15 & 0,13 \\
\hline german nationality $=1$ & 0,91 & 0,91 & 0,93 & 0,88 & 1,00 & 0,98 & 1,00 & 1,00 \\
\hline married & 0,58 & 0,36 & 0,32 & 0,70 & 0,53 & 0,24 & 0,42 & 0,69 \\
\hline age of the youngest child & 2,69 & 1,61 & 1,27 & 4,25 & 2,21 & 1,36 & 1,79 & 3,54 \\
\hline No. of observations & 2332 & 144 & 1200 & 1387 & 717 & 46 & 499 & 305 \\
\hline
\end{tabular}

Note: The number of observations of the weighted figures is smaller than the number of observation in the cross section estimates, because using the weighting factor of the SOEP excludes first interviews (Pannenberg et al. 2005). 1 FT: Full-time employees, PT: Part-time employees according to the self-assessment of the respondent (including marginal employment). 
Table 8: Number of part-time employees by year and group

\begin{tabular}{|c|c|c|c|c|c|c|c|c|c|c|c|c|}
\hline \multirow[b]{2}{*}{ Year } & \multicolumn{3}{|c|}{ West German men } & \multicolumn{3}{|c|}{ West German women } & \multicolumn{3}{|c|}{ East German men } & \multicolumn{3}{|c|}{ East German women } \\
\hline & PT (all) & PT w/ SS & ME & PT (all) & PT w/ SS & ME & PT (all) & PT w/ SS & ME & PT (all) & PT w/ SS & ME \\
\hline 1984 & 34 & 19 & 15 & 643 & 480 & 163 & & & & & & \\
\hline 1985 & 39 & 24 & 15 & 506 & 468 & 38 & & & & & & \\
\hline 1986 & 35 & 31 & 4 & 437 & 369 & 68 & & & & & & \\
\hline 1987 & 15 & 10 & 5 & 408 & 386 & 22 & & & & & & \\
\hline 1988 & 19 & 15 & 4 & 445 & 414 & 31 & & & & & & \\
\hline 1989 & 30 & 25 & 5 & 563 & 503 & 60 & & & & & & \\
\hline 1990 & 35 & 26 & 9 & 543 & 498 & 45 & 9 & 9 & 0 & 279 & 279 & 0 \\
\hline 1991 & 49 & 31 & 18 & 657 & 569 & 88 & 10 & 9 & 1 & 175 & 172 & 3 \\
\hline 1992 & 46 & 30 & 16 & 610 & 566 & 44 & 6 & 5 & 1 & 142 & 138 & 4 \\
\hline 1993 & 50 & 35 & 15 & 656 & 589 & 67 & 11 & 8 & 3 & 133 & 128 & 5 \\
\hline 1994 & 35 & 21 & 14 & 659 & 568 & 91 & 13 & 10 & 3 & 146 & 141 & 5 \\
\hline 1995 & 72 & 44 & 28 & 762 & 641 & 121 & 15 & 12 & 3 & 193 & 186 & 7 \\
\hline 1996 & 70 & 48 & 22 & 717 & 622 & 95 & 8 & 7 & 1 & 175 & 167 & 8 \\
\hline 1997 & 86 & 62 & 24 & 762 & 641 & 121 & 12 & 8 & 4 & 176 & 164 & 12 \\
\hline 1998 & 94 & 63 & 31 & 837 & 706 & 131 & 16 & 8 & 8 & 189 & 173 & 16 \\
\hline 1999 & 84 & 56 & 28 & 797 & 655 & 142 & 22 & 15 & 7 & 199 & 184 & 15 \\
\hline 2000 & 163 & 104 & 59 & 1665 & 1370 & 295 & 43 & 28 & 15 & 316 & 272 & 44 \\
\hline 2001 & 151 & 108 & 43 & 1548 & 1272 & 276 & 33 & 21 & 12 & 294 & 263 & 31 \\
\hline 2002 & 151 & 93 & 58 & 1828 & 1520 & 308 & 45 & 26 & 19 & 320 & 279 & 41 \\
\hline 2003 & 151 & 97 & 54 & 1697 & 1405 & 292 & 45 & 30 & 15 & 328 & 291 & 37 \\
\hline 2004 & 160 & 95 & 65 & 1761 & 1409 & 352 & 57 & 30 & 27 & 360 & 304 & 56 \\
\hline 2005 & 145 & 97 & 48 & 1610 & 1259 & 351 & 38 & 22 & 16 & 318 & 287 & 31 \\
\hline 2006 & 162 & 104 & 58 & 1679 & 1316 & 363 & 43 & 25 & 18 & 341 & 302 & 39 \\
\hline 2007 & 190 & 119 & 71 & 1817 & 1425 & 392 & 52 & 33 & 19 & 408 & 345 & 63 \\
\hline 2008 & 175 & 113 & 62 & 1620 & 1280 & 340 & 41 & 26 & 15 & 337 & 287 & 50 \\
\hline 2009 & 186 & 123 & 63 & 1721 & 1311 & 410 & 53 & 33 & 20 & 383 & 340 & 43 \\
\hline 2010 & 163 & 91 & 72 & 1561 & 1199 & 362 & 54 & 36 & 18 & 335 & 294 & 41 \\
\hline
\end{tabular}

Note: "PT (all)" shows the number of part-time employees considered in equation A, "PT w/ ss" refer to the number of part-time employees covered with social security and "ME" refers to the marginal employees. The shaded areas show the years taken into account to estimate the trend in part-time remuneration. 


\section{Literature}

Aaronson, D. and E. French (2004): The Effect of Part-Time Work on Wages: Evidence from the Social Security Rules, Journal of Labor Economics, Vol. 22(2), 329-25.

Allaart, P. and L. Bellmann (2007): Reasons for Part-time work: an empirical analysis for Germany and the Netherlands, International Journal of Manpower, Vol. 28(7), 329-352.

Ashenfelter O. C., H. Farber and M. R. Ransom (2010): Labor market monopsony, Journal of Labor economics. - Chicago, Ill : Univ. of Chicago Press, Vol. 28.2010(2), 203-21.

Baffoe-Bonnie, J. (2004): Interindustry part-time and full-time wage differentials: regional and national analysis, Applied Economics, Vol. 36, 107-118.

Bardasi, E. and J. C. Gornick (2008): Working for less? Women's part-time wage penalties across countries, Feminist economics, Vol. 14, 37-72.

Barzel, Y. (1973): The determination of daily hours and wages, Quarterly Journal of Economics, Vol. 87(2), 220- 238.

Beblo, M. und E. Wolf (2002): How much does a year off cost? Estimating the Wage Effects of Employment Breaks and Part-Time Periods, Cahiers Économiques de Bruxelles, Vol. 45(2), 191-217.

Bell, L. and R. B. Freeman (2001): The Incentive for Working Hard: Explaining Hours Worked Differences in the U.S. And Germany, Labour Economics, Vol. 8(2), 181202.

Bell, D., S. Otterbach and A. Sousa-Poza (2012): Work Hours Constraints and Health, Annales d'Économie et de Statistique, Vol. 105-106, 35-54.

Bhaskar, V., A. Manning and T. To (2002): Oligopsony and monopsonistic competition in labor markets. Journal of Economic Perspectives, Vol. 16(2), 155-74.

Blank, R. M. (1990): Are Part-Time Jobs bad Jobs? In: Burtless, G. (Hrsg.): A Future of Lousy Jobs? The Changing Structure of U.S. Wages, Brookings Institution, Washington D. C, 123-155.

Bosch, N., A. Deelen and R. Euwals (2010): Is Part-time Employment Here To Stay? Evidence from the Dutch Labour Force Survey 1992-2005, Labour, Vol. 24(1), 35-54.

Booth, A. und M. Wood (2008): Back-to-Front Down-Under? Part-Time/Full-Time Wage Differentials in Australia, Industrial Relations: A Journal of Economy and Society, Vol. 47(1), 114-135.

Borjas, G. J. (1980): The Relationship Between Wages and Weekly Hours of Work: The Role of Division Bias, Journal of Human Resources, Vol. 15(3), 409-423.

Brehmer, W. und H. Seifert (2008): Sind atypische Beschäftigungsverhältnisse prekär? Eine empirische Analyse sozialer Risiken, Zeitschrift für Arbeitsmarktforschung, Vol. 41(4), 501-531.

Brenke, K. (2011): Anhaltender Strukturwandel zur Teilzeitbeschäftigung, DIW Wochenbericht Nr. 42, 3-12.

Bresnahan, T., Brynjolfsson, E. and L. Hitt (2002): Information Technology, Workplace Organization and the Demand for Skilled Labor: Firm-level Evidence, The Quarterly Journal of Economics, Vol. 117(1), 339-76.

Browning, M. (1992): Children and Household Economic Behavior, Journal of Economic Literature, Vol. 30(3), 1434-1475. 
Buligescu, B.; de Crombrugghe, D.; Mentesoglu, G. und R. Montizaan (2009): Panel estimates of the wage penalty for maternal leave, Oxford Economic Papers, Vol. 61, i35-i65.

Caroli, E. and J. Van Reenen (2001): Skill-biased organizational change? Evidence from a panel of British and French establishments, The Quarterly Journal of Economics, Vol. 116(4), 1449-92.

Connolly, S. und M. Gregory (2008): The part-time pay penalty: earnings trajectories of British Women, Oxford Economic Papers, Vol. 61, i76-i97.

Constant, A. F. and S. Otterbach (2011): Work Hours Constraints: Impacts and Policy Implications, IZA Policy Paper No. 35.

Destatis 2014: Atypische Beschäftigung, Kernerwerbstätige nach einzelnen Erwerbsformen, Ergebnisse des Mikrozensus.

Ermisch, J.F. and R. E. Wright (1991): Wage offers and full-time and part-time employment by British women, The Journal of Human Resources, Vol. 25(1), $111-133$.

Eurostat (2013): Full-time and part-time employment (Labor Force Serie), online database of the European Commission.

Euwals, R. and M. Hogerbrugge (2006): Explaining the growth of part-time employment : factors of supply and demand, Labour, Vol. 20(3), 533-557.

Fernandez-Kranz, D.; Paul, M. und N. Rodriguez-Planas (2011): Part-Time Work, FixedTerm Contracts, and the Returns to Experience, IZA-Discussion Paper No. 5815.

Fischer, G., V. Dahms, S. Bechmann, F. Bilger, M. Frei, J. Wahse and I. Möller (2008): Langfristig handeln, Mangel vermeiden: Betriebliche Strategien zur Deckung des Fachkräftebedarfs. Ergebnisse des IAB-Betriebspanels 2007, IABForschungsbericht Nr. 3/2008.

Grözinger, G.,W. Matiaske and V. Tobsch (2008): Arbeitszeitwünsche, Arbeitslosigkeit und Arbeitszeitpolitik, WSI Mitteilungen (2), 92-98.

Gustafsson S., C. Wetzels and E. Kenjoh (2003): Employment Choices and Pay Differences between Non-Standard and Standard Work in U.K., Germany, Netherlands and Sweden, in: Houseman, S. and Osawa, M. (Hrg.): Nonstandard Work Arrangements in Japan, Europe, and the United States, Kalamazoo, Michigan: Upjohn Institute for Employment Research, 215-266.

Hamermesh, D. S. and A. Rees (1988): The Economics of Work and Pay. New York.

Hardoy, I. and P. Schøne (2006): The Part-time Wage Gap in Norway: How Large is it Really? British Journal of Industrial Relations, Vol. 44(2), 263-282.

Hirsch, B. (2005): Why do Part-Time Workers Earn Less? The Role of Workers and Job Skills, Industrial and Labor Relations Review, Vol. 58(4), 525-551.

Holst, E. (2007): Arbeitszeitwünsche von Männern und Frauen liegen näher beieinander als tatsächliche Arbeitszeiten, DIW Wochenbericht Nr. 14-15, 209-215.

Holst, E. (2009): Vollzeitbeschäftigte wollen kürzere, Teilzeitbeschäftigte wollen längere Arbeitszeiten, DIW Wochenbericht Nr. 25, 409-415.

Holst, E. und H. Seifert (2012): Arbeitszeitpolitische Kontroversen im Spiegel der Arbeitszeitwünsche, WSI Mitteilungen Nr. 2, 1-11.

Körner, T.; Meinken, H. and K. Puch (2013): Wer sind die ausschließlich geringfügig Beschäftigten? Eine Analyse nach sozialer Lebenslage, Wirtschaft und Statistik, Januar 2013, Statistisches Bundesamt, Wiesbaden.

Kranz, D. F. and N. Rodriguez-Planas (2011): The Part-Time Pay Penalty in a segmented Labour market, Labour Economics, Vol. 18(5), 591-606. 
Landers, R. M., Rebitzer, J. B. and L. J. Taylor (1996): Rat Race Redux: Adverse Selection in the Determination of Work Hours in Law Firms, American Economic Review, Vol. 86(3), 329-348.

Leszczensky, M., R. Frietsch, B. Gehrke and R. Helmrich (2009): Bildung und Qualifikation als Grundlage der technologischen Leistungsfähigkeit Deutschlands, HIS Forum Hochschule 6/2009.

Lindbeck, A. and D. J. Snower (2000): Multi-task Learning and the Reorganisation of Work: From Tayloristic to Holistic Organisation, Journal of Labor Economics, Vol. $18,353-376$.

Manning, A. (2003): The real thin theory: Monopsony in modern labour markets, Labour Economics, Vol. 10(2), 105-131.

Manning, A. (2011): Imperfect competition in the labor market, in: Ashenfelter, O.C. and Card, D.E., Handbook of Labor Economics, Vol. 4B, 973-1041, Amsterdam, Elsevier

Manning, A. und B. Petrongolo (2008): The Part-time pay penalty for Women in Britain, The Economic Journal, Vol. 118, F28-F51.

Manning, A. und $\mathrm{H}$. Robinson (2004): Something in the way she moves: A fresh look at an old gap, Oxford Economic Papers, Vol. 56(1), 169-188.

Matteazzi, E.; Pailhé, A. und A. Solaz (2012): Part-time wage penalties in Europe. A matter of selection or segregation? ECINEQ Working Paper 2012-250, Society for the Study of Economic Inequality, Palma de Mallorca, Spanien.

McGinnity, F. und P. McManus (2007): Paying the Price for Reconciling Work and Family, Comparing the wage penalty for Women's Part-Time Work in Britain, Germany and the United States, Journal of Comparative Policy Analysis: Research and Practice, Vol. 9(2), 115-234.

Moffitt, R. (1984): The estimation of a joint wage-hours labor supply model, Journal of Labor Economics, Vol. 4(2), 550-566.

Montgomery, M. (1988): On the determinants of Employer Demand for Part-Time Workers, Review of Economics and Statistics, Vol. 70(1), 112-117.

OECD (2010): How good is part-time Work? OECD Employment Outlook 2010, Paris.

Oi, W. (1962): Labor as a quasi-fixed factor, Journal of Political Economy, Vol. 70, 538555.

Olsen, W. und S. Walby (2004): Modelling gender pay gaps, Working Paper Series No. 17, Equal Opportunities Commission, Manchester, UK.

O'Reilly, J. and S. Bothfeld (2002): What happens after working part time? Integration, maintenance or exclusionary transitions in Britain and Western Germany. Cambridge Journal of Economics, Vol. 26(4), 409-439.

Pannenberg, M.; Pischner, R.; Rendtel, U.; Spiess, M. and G. G Wagner (2005): Sampling and Weighting, in: J. P. Haisken-DeNew and J. R. Frick (eds.), Desktop Companion to the German Socio-Economic Panel (SOEP) - Version 8.0, Berlin.

Paul, M. (2012): Is there a Causal Effect of Working Part-Time on Today's and Future Wages? University of Duisburg-Essen, mimeo.

Riphan, R. T. and P. Trübswetter (2007): Population Aging and Trends in the Provision of Continued Education, RatSWD Working Paper No. 15.

Rodgers, J. R. (2004): Hourly Wages of Full-Time and Part-Time Employees in Australia, Australian Journal of Labour Economics, Vol. 7, 215-238.

Rosen, S. (1986): The Theory of Equalizing Differences, in: O. Ashenfelther und D. Card (Hg.): The Handbook of Labor Economics, Vol. 1, 641-92. 
Russo, G. and W. Hassink (2008): The Part-time wage Gap: A career perspective, De Economist, Vol. 156(2), 145-174.

Schröder, M.; Siegers, R. and C. K. Spieß (2012): Familien in Deutschland (FiD) Enhancing Research on Families in Germany. SOEPpapers Nr. 556.

Schwarze, (1998): Wer trägt die pauschale Lohnsteuer bei geringfügiger Beschäftigung? Eine Analyse der Stundenlöhne erwerbstätiger Frauen, in H. P. Galler and G. Wagner (Eds.): Empirisch Forschung und wirtschaftspolitische Beratung, 215225, Frankfurt.

Statistisches Bundesamt 2012: Teilzeitquoten (Auswertungen auf Anfrage).

Tummers, M. P. and I. Woittiez (1991): A simultaneous wage and labor supply model with hours restrictions, The Journal of Human Resources, Vol. 26(3), 393- 423.

Voss, D. and C. Weinkopf (2012): Niedriglohnfalle Minijob, WSI-Mitteilungen, Heft 1, 512.

Wagner, G. G.; Frick, J. R. and J. Schupp (2007): The German Socio-Economic Panel Study (SOEP) - Scope, Evolution and Enhancements. Schmollers Jahrbuch, Vol. 127(1), 139-169.

Wahlberg, R. (2008a): The Part-time Penalty for Natives and Immigrants, Working Paper in Economics No. 314, School of Business, Economics and Law, University of Gothenburg.

Wahlberg, R. (2008b): The Part-time Penalty in Sweden: Evidence from Quantile Regression, Working Paper in Economics No. 315, School of Business, Economics and Law, University of Gothenburg.

Wilson, J. (2010): Maternal Movements to part-time employment: what is the penalty? Sheffield Economic Research Paper Series No. 2010002, Sheffield, UK.

Wolf, E. (2002): Lower Wage Rates for Lesser Hours? A Simultaneous Wage-Hours Model for Germany, Labour Economics, Vol. 9(5), 643-663.

Wooden, M., D. Warren and R. Drago (2009): Working Time Mismatch and Subjective Well-being, British Journal of Industrial Relations, Vol. 47(1), 147-179. 